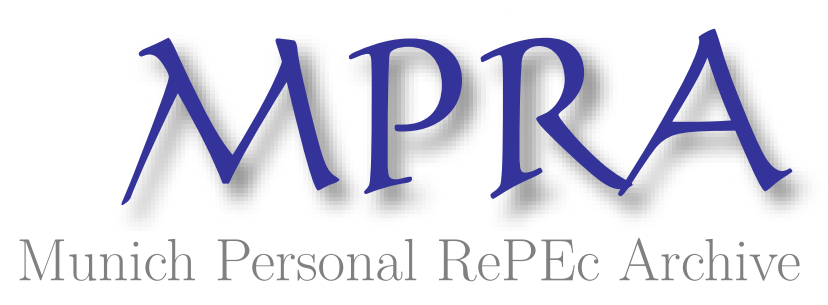

\title{
Transfer Pricing by Multinational Firms: New Evidence from Foreign Firm Ownerships
}

\author{
Cristea, Anca D. and Nguyen, Daniel X. \\ University of Oregon, University of Copenhagen
}

7 December 2013

Online at https://mpra.ub.uni-muenchen.de/61922/

MPRA Paper No. 61922, posted 09 Feb 2015 15:05 UTC 


\title{
Transfer Pricing by Multinational Firms: New Evidence from Foreign Firm Ownerships*
}

\author{
Anca D. Cristea ${ }^{\dagger}$ \\ University of Oregon
}

\author{
Daniel X. Nguyen $\ddagger$ \\ University of Copenhagen
}

December 2013

\begin{abstract}
Using a firm-level panel dataset covering the universe of Danish exports between 1999 and 2006, we find robust evidence for profit shifting by multinational corporations (MNC) through transfer pricing. Our triple difference estimation method corrects for a downward bias in previous studies. The bias results from MNCs adjusting their arm's length prices to obscure the extent of their transfer price manipulations. Our identification strategy exploits the movement in export prices to a destination in response to: (1) the establishment of a foreign affiliate by an exporter to that destination, and (2) a change in the foreign corporate tax rates. After acquiring an affiliate in a country with a corporate tax rate lower than in the home country, Danish multinationals reduce the unit values of their exports there between 5.7 to 9.1 percent, on average. This reduction corresponds to $\$ 141$ million in underreported export revenues in year 2006 , which translates into a loss in tax income equal to 3.24 percent of Danish MNCs' tax returns.
\end{abstract}

$J E L: \mathrm{F} 23, \mathrm{H} 25, \mathrm{D} 23$

Keywords: corporate tax, transfer prices, arm's length principle, triple difference, foreign ownership

${ }^{*}$ This work could not have been accomplished without tremendous help from Rasmus Jorgensen. In addition, we thank Bruce Blonigen, Eyal Dvir, Doireann Fitzgerald, David Hummels, Don Lee, Kalina Manova, Jakob Munch, Pascalis Raimondos-Moller, Tim Schmidt-Eisenlohr, Andreas Waldkirch, Caroline Weber, Chong Xiang and seminar participants at the Colby College, Penn State University, Stanford University, University of Oregon and Ljubljana Empirical Trade Conference (LECT 2013) for helpful comments and suggestions. We are grateful to Mary Ceccanese and the Office of Tax Policy Research at the University of Michigan for help with the World Tax Database. All remaining errors are our own.

${ }^{\dagger}$ Corresponding Author: Department of Economics, University of Oregon, 1285 University of Oregon, Eugene, OR 97403, USA. E-mail: cristea@uoregon.edu.

${ }^{\ddagger}$ Contact: Department of Economics, University of Copenhagen. E-mail: daniel.x.nguyen@gmail.com 


\section{Introduction}

Large budget deficits and a sluggish world economy have forced governments worldwide to tighten regulations and intensify corporate audits in the hope of raising tax revenues. Among the key targets sought by tax authorities are multinational corporations (MNC). While their rapidly growing global activities generate large operating profits, MNCs avoid paying taxes on a substantial portion of their profits by shifting taxable income to jurisdictions with low corporate tax rates. ${ }^{1}$ Concerns over tax avoidance have intensified so much in recent years that international taxation regulation has become a top priority on the agenda of the OECD and G8 country meetings. ${ }^{2}$

A vehicle commonly used by MNCs to shift income across countries is intra-firm trade. The pricing of goods exchanged between related parties - known as transfer pricing - provides MNCs a tool to allocate incomes across affiliated entities in different tax jurisdictions. By underpricing the exports shipped from a high tax country to a low tax country, an MNC is able to reduce its effective global tax rate. ${ }^{3}$ A classic case study of this profit shifting strategy involved the chemical company Du Pont de Nemours. In 1959, Du Pont created a wholly-owned Swiss marketing and sales subsidiary - Du Pont International S.A. ("DISA"), which distributed all Du Pont chemical products outside the USA. According to court documents, Du Pont's "internal memoranda were replete with references to tax advantages, particularly in planning prices on Du Pont goods to be sold to [DISA]. The tax strategy was simple. If Du Pont sold its goods to [DISA] at prices below fair market value, [DISA], upon resale of the goods, would recognize the greater part of the total profit (i.e., manufacturing and selling profits). Since this foreign subsidiary could be located in a country where its profits would be taxed at a much lower level than the parent Du Pont would be taxed here, the enterprise as a whole would minimize its taxes." ${ }^{4}$ Given this evidence of profit shifting, the IRS rejected Du Pont's transfer pricing position and adjusted its US income upwards.

In response to income shifting strategies seen in E. I. Du Pont de Nemours and Company

\footnotetext{
${ }^{1}$ In Denmark, our data source for the empirical analysis, the evidence suggests that. " $30 \%$ of all foreign and $28 \%$ of all Danish multinational companies have paid no company tax in the period 2006-2008." (KPMG, 2010).

${ }^{2}$ In a recent address at the World Economic Forum in Davos, the British prime minister expressed the intention to "use the G8 [presidency] to drive a more serious debate on tax evasion and tax avoidance.[...] There are some forms of avoidance that have become so aggressive [...] it is time to call for more responsibility and for governments to act accordingly." (Cameron, 2013). Soon after Davos, the OECD (2013) published a report calling for the participation of all members to a "comprehensive action plan" to reform the current tax rules.

${ }^{3}$ Another common method to shift profits across locations is debt financing. Given that the interest on debt is tax deductible, MNCs benefit from having affiliates in low tax locations lend to affiliates in high tax locations. For empirical evidence, see Huizinga, Laeven, and Nicodeme (2008) and Egger et al. (2010) among others.

${ }^{4}$ E. I. Du Pont de Nemours and Company v. the United States., 608 F.2d 445 (Fed. Cir. 1979)
} 
$v$. the United States, tax authorities around the world have established regulations on recording internal prices for taxation purposes. The arm's length principle of taxation requires MNCs to invoice intra-firm transactions at the same arm's length price charged to unaffiliated parties. In practice, however, the regulations leave enough room for companies to strategically choose arm's length prices in order to hide transfer pricing manipulations. This makes identifying income shifting activities a challenge for both tax authorities and empirical researchers.

In this paper we estimate the extent to which MNCs manipulate both (1) transfer prices to controlled affiliates and (2) arm's length prices to uncontrolled third parties in order to reduce their global tax burdens. To guide our empirical analysis, we use a theory set-up that formalizes the taxation problem of a multinational corporation in a partial equilibrium framework. ${ }^{5} \mathrm{~A}$ known prediction arising from this model is that in the presence of tax differences across countries, multinational firms have the incentive to manipulate transfer prices in order to shift income to the country with lower tax rates.

This study examines an overlooked prediction of the standard theory: that firms will also manipulate their arm's length price in the direction of the transfer price as a result of corporate tax differences across locations. This second price manipulation obscures the extent of the first one, allowing MNCs to comply with the arm's length principle of taxation and, at the same time, engage in income shifting. The total income shifted out of the home country is the cumulation of these two manipulations. Previous studies that focused only on movements in transfer prices underestimate the full extent of income shifting.

This study's prediction that MNCs' manipulate arm's length prices has important implications for both econometricians and tax authorities. It suggests that MNCs' arm's length export prices should not be used as comparable uncontrolled prices ("CUP"s) for contemporaneous intrafirm trade transactions. By comparing an MNC's transfer price to its arm's length price instead of a true reference $\mathrm{CUP}^{6}$, tax authorities and researchers underestimate the extent to which the MNC manipulates prices in order to shift profits. ${ }^{7}$ The contribution of our empirical analysis is to mitigate

\footnotetext{
${ }^{5}$ The theory set-up follows Bernard, Jensen, and Schott (2006).

${ }^{6}$ As we will explain in the theory section, we define a true reference CUP as the price of a good sold to an unrelated party, determined in the absence of any tax saving incentives.

${ }^{7}$ Several recent papers argue that the arm's length taxation principle is a distortionary rule because even in the absence of tax differences across countries, profit maximizing MNCs may optimally set intra-firm prices at a different level from arm's length prices. In an offshoring model with financing frictions, Kreuschnigg and Devreux (2012) show that even absent tax rate differences across countries, a parent firm may still shift income via transfer pricing in order
} 
this bias. Specifically, we use a triple difference estimation strategy to impute an unbiased difference between an MNC's export unit value and the true reference CUP. The export unit value comprises both the transfer price and arm's length price. Its deviation from the true CUP, multiplied by the quantity traded, represents the total revenue shifted by MNCs out of the home country.

Our estimation strategy requires rich firm and transaction level data. We exploit information on multinational firms that establish new foreign affiliates in markets to which they export. By comparing the export unit values before and after acquiring an affiliate in a foreign country, we identify the change in export unit values related to the foreign acquisition. Using a triple difference method, we are able to discern between (1) the changes in export unit values associated with differences in corporate tax rates across jurisdictions and (2) the changes in export unit values associated with an internal reorganization of the firm following the affiliate acquisition.

In implementing our estimation strategy, we use firm and transaction level data for Denmark for the period 1999 - 2006. There are several advantages in departing from U.S. data. First, Denmark has a territorial taxation system, unlike the residential taxation system in the U.S. ${ }^{8}$ This distinction is relevant for our purposes because the potential gains from transfer price manipulations, and thus the incentive to shift profits internationally, are expected to be larger under territorial taxation systems (Hines, 1996; Swenson, 2001). Moreover, the territorial taxation system is the most commonly used taxation system in the world, which makes our findings more generalizable to other environments. Second, historically Denmark has imposed moderate levels of corporate tax rates. This implies that at each point in time there exists a sizeable number of important foreign markets that fall into a high tax, or a low tax regime category, defined relative to the tax rate in the home country. ${ }^{9}$ We exploit this feature of our data by allowing for the elasticity of transfer prices with respect to corporate tax rates to differ for high tax versus low tax regime countries. ${ }^{10}$

This paper provides significant empirical evidence showing that Danish multinational firms use transfer pricing to shift income to countries with lower tax rates. We find that a 10 percentage

to relax the financing constraints faced by the foreign affiliate. Raimondos-Moller and Scharf (2002) emphasize the inefficiency of the arm's length standard in the context of a non-cooperative tax competition game among countries.

${ }^{8}$ In a residential taxation system, residents are taxed for income earned worldwide. However, in a territorial system only income earned from activities performed in that country gets taxed.

${ }^{9}$ In this paper, we define a low (high) tax regime as a country with a lower (higher) tax rate than the home country. This is not to be confused with the terminology from other papers where low tax jurisdictions are considered tax havens (Desai, Foley, and Hines, 2006).

${ }^{10} \mathrm{~A}$ reason to suspect asymmetric transfer price effects comes from the unbalanced effort of tax authorities to verify profit shifting in the case of an increase, as opposed to a decrease in the domestic tax base. 
point decrease in the tax rate of a low tax regime country results in a 5.7 percent drop in the export unit values of MNCs owning affiliates in that country, compared to non-affiliated exporters. This drop in unit values is more pronounced for differentiated goods (6.5 percent), and even more so for the subsample of firms who establish new affiliates during the sample period (9.1 percent).

Our findings contribute to several areas of on-going research. A large empirical literature documents the profit shifting behavior of MNCs as a response to differences in corporate tax rates across countries. ${ }^{11}$ While most studies find that MNCs earn higher profit margins in low corporate tax locations, they do not shed light on the mechanisms by which profit shifting occurs. From a policy perspective, these results are less informative as they provide no guidance on the kind of regulation that is needed to secure a country's income tax base.

Few papers provide direct evidence for transfer pricing as an important mechanism of profit shifting. While the empirical strategy generally consists of relating the difference in product unit values between intra-firm and arm's length trade to the gap in corporate tax rates across trade partners, the findings are more heterogeneous. This is partly because earlier studies have relied on trade datasets available at industry or product level (Swenson, 2001; Clausing, 2003). ${ }^{12}$ An implication of the data aggregation is that the observed average unit values of traded goods embed compositional effects such as firm heterogeneities within a product category, or product differences within an industry. This has a direct effect on the estimates, potentially biasing them downwards due to attenuation bias, or upwards if comparing product prices from firms heterogeneous in productivity. ${ }^{13}$ The paper most closely related to ours that uses U.S. micro level data is Bernard, Jensen, and Schott (2006). By observing MNCs' exports to affiliated and unrelated parties in a

\footnotetext{
${ }^{11}$ Grubert and Mutti (1991) use U.S. outward FDI data to show that the after-tax profit rates of foreign affiliates are negatively related to effective income tax rates, and that the net capital investments are larger in countries with lower tax rates. Hines and Rice (1994) focus on U.S. FDI in tax havens, and find even larger elasticities of income and of real activity to tax rates. Bartelsman and Beetsma (2003) use OECD industry level data to show that when income shifting occurs, the inverse of the labor cost share becomes a direct function of the corporate tax rate differences across countries. More recently, Egger, Eggert, and Winner (2010) provide evidence that foreign owned plants make lower tax payments than similar domestic counterparts, attributing most of this tax savings to profit rather than debt shifting. For comprehensive surveys of the literature see Hines (1999) and Devreux (2006).

${ }^{12}$ Swenson (2001) uses product level U.S. import data to examine the response of average unit values to import tariffs and corporate tax rate differences across countries. While she finds evidence for income shifting through transfer pricing, the effects are economically small. Using detailed monthly price data for over 22,000 products traded by the U.S., Clausing (2003) brings evidence suggesting significantly larger transfer price manipulations: a 1 percent drop in the foreign corporate tax rate is associated with 0.94 percent lower intra-firm export prices.

${ }^{13}$ Given the abundant evidence on the selection of firms into foreign markets based on productivity levels (Melitz, 2003; Helpman, Melitz, and Yeaple, 2004), it becomes particularly important to conduct the empirical analysis at firm level. In a recent paper, Bauer and Langenmayr (2013) show how setting transfer prices at market values determined by a pool of outside firms leads to systematic overpricing and profit shifting by multinational firms as a consequence of their exceptional productivity levels.
} 
market, Bernard, Jensen, and Schott (2006) are able to construct firm specific price wedges between intra-firm and arm's length transactions, and relate them to differences in tax rates across countries. However, their findings underestimate the extent of profit shifting via transfer pricing if, as argued in this paper, MNCs act strategically by setting arm's length prices closer to the optimal transfer price. Our contribution provides an econometric strategy that accounts for this behavior.

This paper also relates to the recent work on intra-firm trade. The increasing importance of MNCs and the continuous fragmentation of production processes across national borders have accelerated the growth of intra-firm trade as a fraction of world trade. Furthermore, the volume and composition of intra-firm transactions have played a key role in explaining the geography of multinational production (Keller and Yeaple, 2012; Irarrazabal, Moxnes, and Opromolla, 2012; Cristea, 2012). By investigating the discrepancies between the reported and actual trade unit values, this paper documents a generally neglected reason - i.e., corporate taxes - for why intra-firm trade may vary systematically across countries.

The paper proceeds as follows. Section 2 provides a simple theory framework to motivate the empirical analysis. Section 3 describes the estimation strategy, highlighting the sources of identification. The data are detailed in section 4, while the estimation results are discussed in section 5. The main policy implications are summarized in section 6 , and section 7 concludes.

\section{Theory Framework}

This section formalizes the change in export prices determined by the profit shifting motives of multinational corporations. We show how a tax-savvy multinational firm, when faced with exogenous foreign country tax rates that differ from the home country, will set the arm's length and transfer prices so as to maximize the firm's global profit. Both of these prices will differ systematically from the prices set by an identical pure exporter with no foreign affiliates.

Our model follows closely Bernard, Jensen, and Schott (2006) and, as such, we attempt to follow their notation simplifying where possible. Our model reproduces their main predictions. However, while Bernard, Jensen, and Schott (2006) use their set-up to show how tax rate differences across locations affect the gap between an MNC's intra-firm transfer price and its arm's length export price, we extend the analysis to show that in the face of tax saving incentives, the MNC 
responds not only by manipulating its transfer price, but also by changing its arm's length price. And because the direction of change in the arm's length price mimics the direction of change in the transfer price, the resulting price gap conceals the full extent of the MNC's price manipulations. Thus, we argue that the price gap analyzed by Bernard, Jensen, and Schott (2006) and the existing transfer pricing literature does not reflect the full extent of profit shifting undertaken by MNCs.

\subsection{A true Comparable Uncontrolled Price (CUP)}

To begin, we define the arm's length export price of a product transacted between two unrelated parties, neither of whom have any incentives to shift income via price manipulations for the purpose of avoiding taxes. Given the perfect data, tax authorities and econometricians alike would use this price as a true reference price, i.e., true CUP, for comparison with transfer prices. ${ }^{14}$

A firm based in the home country $h$, who exports a product to a foreign destination country $f$, only sells its variety to an unrelated party in that market and has no incentives to alter its price from the profit maximizing level. We label this type of firm a pure exporter, and index it by $x$. We assume that the product is sold in a monopolistically competitive market, where it faces an iso-elastic demand curve. Letting $\sigma$ denote the demand elasticity, the pure exporter sets the export price $p_{x}$ equal to a constant markup over its marginal cost $c$ :

$$
p_{x}=\frac{\sigma}{\sigma-1} c
$$

We term $p_{x}$ the true $C U P$, or alternatively the true reference price for the particular product exported to country $f$. It reflects the true market value of the exported product, when produced by a firm with $\operatorname{cost} c$. For the multinational firm identical to the pure exporter, selling a comparable product to the same destination country, tax authorities would use $p_{x}$ as a benchmark to evaluate transfer prices, if $p_{x}$ were observable. The rest of the section details how the price set by a comparable multinational firm differs from this reference price posted by a pure exporter whenever corporate tax rates differ across the two countries.

\footnotetext{
${ }^{14}$ IRS $\S 1.482-1(d)(1)$ aims to evaluate transfer prices by comparing them to "results realized by [unrelated parties] engaged in comparable transactions under comparable circumstances."
} 


\subsection{Export Prices for a Multinational Corporation}

Next, we consider a multinational corporation that is assumed to be identical to the previous exporting firm in terms of product characteristics, production technology and cost structure. The only difference between the multinational firm and the pure exporter comes from their ownership structure: the MNC owns a foreign affiliate in country $f$, and as such can sell its variety both internally to its foreign affiliate, and to unrelated parties in that market. ${ }^{15}$

To focus the attention on the price distortions driven by taxation motives, we eliminate any production allocation decisions from the problem of the multinational firm and assume that the final good is produced in the home country, and the foreign affiliate only serves a distribution role in its local market. ${ }^{16}$ We also simplify the exposition by assuming away any frictions affecting international transactions.

The parent and foreign affiliate are establishments integrated in the same corporation, but for tax purposes they act as separate entities. Each entity makes pricing decisions so as to maximize after tax profits. The parent keeps two sets of books: one for internal purposes, where intra-firm prices are optimally chosen to maximize global profits, and one for taxation purposes, where intrafirm transfers are evaluated following the arm's length principle.

\section{Foreign Affiliate's Problem:}

The foreign affiliate only trades with the parent firm (i.e., intra-firm trade). It imports the final product at an internal price $p_{i}$ and re-sells it in the local market at a price $p_{f} .{ }^{17}$ Subject to the isoelastic local demand for its variety $q_{f} \equiv q_{f}\left(p_{f} ; \sigma\right)$, the foreign affiliate posts a price $p_{f}$ to maximize its after tax profits.

The affiliate's income before tax is given by:

$$
\tilde{\pi}_{f}=\left(p_{f}-p_{i}\right) q_{f}
$$

\footnotetext{
${ }^{15}$ These unrelated parties could be thought of as third-party distributors or local retailers that rebrand the product.

${ }^{16}$ This simplification circumvents the discussion about offshoring decisions that arises with the expansion of multinational production. Recent evidence suggests that a significant share of intra-firm trade is motivated by distribution rather than production purposes. Using data for Germany, Krautheim (2012) and Kleinert and Toubal (2013) document that 46 percent of the foreign affiliates of German multinationals are classified as wholesale. The ratio of sales by wholesale affiliates relative to affiliates in the same sector as their parent ranges between 0.3 and 1 .

${ }^{17}$ The internal price is also known as an 'incentive rate', and is chosen by the parent to incentivize the manager of the foreign affiliate to make optimal purchase decisions that maximize total corporation profits.
} 
where the fixed cost is set to zero for simplicity.

For tax purposes, the affiliate has to report an intra-firm invoice price that is consistent with the transfer price regulations. Denoting the transfer price reported to the tax authorities by $p_{t}$, the tax paid by the foreign affiliate is given by:

$$
\operatorname{tax}_{f}=\tau_{f}\left(p_{f}-p_{t}\right) q_{f}
$$

where $\tau_{f}$ is the statutory corporate tax rate in the foreign country. This implies that the after tax profit maximized by the affiliate firm is given by:

$$
\begin{aligned}
\pi_{f} & =\tilde{\pi}_{f}-\operatorname{tax}_{f} \\
& =\left(1-\tau_{f}\right) p_{f} q_{f}-\left(p_{i}-\tau_{f} p_{t}\right) q_{f}
\end{aligned}
$$

Since the foreign affiliate has a monopoly on the product variety sold in the local market, and faces a demand with constant elasticity $\sigma$, it follows that the optimal sale price set by the affiliate is:

$$
p_{f}^{*}=\frac{1}{1-\tau_{f}} \frac{\sigma}{\sigma-1}\left(p_{i}-\tau_{f} p_{t}\right)
$$

\section{Parent Firm's Problem:}

The parent firm produces a single product at a constant marginal cost $c$ (which is the same as the pure exporter), and exports it to the foreign affiliate as well as to unrelated parties located in the same foreign market $f$. The foreign affiliate demands the quantity $q_{f}$ based on the internal price $p_{i}$ and the transfer price $p_{t}$ provided to it by the parent. The parent also posts an arm's length price $p_{a}$ for the sale of its good to unrelated parties. The parent faces an arm's length demand $q_{a} \equiv q_{a}\left(p_{a} ; \sigma\right)$ with the same constant elasticity $\sigma$ as the affiliate. ${ }^{18}$

The parent's objective is to maximize after-tax corporate profits. The pre-tax profit of the parent firm can be written as:

$$
\tilde{\pi}_{h}=p_{a} q_{a}+p_{i} q_{f}-c\left(q_{a}+q_{f}\right)
$$

where again we assume that fixed costs are zero for simplicity.

\footnotetext{
${ }^{18}$ We implicitly assume that the parent can rebrand the variety for arm's length sales to prevent cannibalization of the affiliate's sales.
} 
The transfer price $p_{t}$ reported to the foreign tax authorities is also reported to the home country's tax authorities. The resulting tax paid by the parent firm is given by:

$$
\operatorname{tax}_{h}=\tau_{h}\left[p_{a} q_{a}+p_{t} q_{f}-c\left(q_{a}+q_{f}\right)\right]
$$

where $\tau_{h}$ is the statutory tax rate in the home country, and it could be greater, equal or less than the foreign country tax rate $\tau_{f}$. This leads to the after-tax headquarter profits equal to:

$$
\begin{aligned}
\pi_{h} & =\tilde{\pi}_{h}-\operatorname{tax}_{h} \\
& =\left(1-\tau_{h}\right)\left[\left(p_{a} q_{a}-c\left(q_{a}+q_{f}\right)\right]+p_{i} q_{f}-\tau_{h} p_{t} q_{f}\right.
\end{aligned}
$$

The parent firm chooses the internal price $p_{i}$, the transfer price $p_{t}$, and the arm's length price $p_{a}$ such that it maximizes the global corporate profits, denoted by $\Pi$ :

$$
\begin{aligned}
\Pi & =\pi_{h}+\pi_{f} \\
& =\left(1-\tau_{h}\right)\left[p_{a} q_{a}-c\left(q_{a}+q_{f}\right)\right]+\left(1-\tau_{f}\right) p_{f}^{*} q_{f}-\left(\tau_{h}-\tau_{f}\right) p_{t} q_{f}
\end{aligned}
$$

A few things are worth pointing out about equation (9). First, while the intra-firm price $p_{i}$ does not enter the expression for after-tax corporate profits directly, the level of $p_{i}$ implicitly affects the after-tax profits via its impact on the affiliate's local resale price $p_{f}^{*}$ (see equation (5)). Similarly, the transfer price $p_{t}$ has both a direct effect on the after-tax corporate profits, as well as an indirect effect operating via its impact on $p_{f}^{*}$. Finally, the quantities $q_{f}$ and $q_{a}$ are functions of $p_{f}$ and $p_{a}$, respectively, and of the demand elasticity $\sigma$.

Recognizing this tax avoidance incentive of MNCs, many governments around the world have adopted the arm's length principle of taxation to prevent intra-firm profit transfers and thus protect their income tax base. This principle regulates the intra-firm transaction price reported for taxation purposes, which must be set at the same level as between unaffiliated parties. Whenever a multinational firm fails to comply with the arm's length principle, it risks a penalty, which takes the following functional form: ${ }^{19}$

$$
\frac{\lambda}{2}\left[\left(p_{a}-p_{t}\right) q_{f}\right]^{2}
$$

\footnotetext{
${ }^{19}$ Bernard, Jensen, and Schott (2006) and Swenson (2001) use penalty functions very similar to this one.
} 
This penalty function assumes that the home country's tax authorities use the MNC's arm's length price as a comparable uncontrolled price (CUP) ${ }^{20}$ The quadratic form reflects higher penalties for substantial or gross misstatements of the export values. ${ }^{21}$ The parameter $\lambda$ captures both the probability with which tax authorities contest the firm's transfer pricing strategy, as well as the fraction of the mis-reported income that needs to be paid as penalty.

The first order conditions from maximizing equation (9) subject to penalty charges are:

$$
\begin{aligned}
& {\left[p_{a}\right]: } p_{a}-\frac{\sigma}{\sigma-1} c+\frac{\lambda\left(p_{a}-p_{t}\right) q_{f}^{2} p_{a}}{\left(1-\tau_{h}\right)(\sigma-1) q_{a}}=0 \\
& {\left[p_{i}\right]: \quad } p_{i}-\tau_{h} p_{t}-\left(1-\tau_{h}\right) c-\lambda\left(p_{a}-p_{t}\right)^{2} q_{f}=0 \\
& {\left[p_{t}\right]: \quad \frac{\partial q_{f}}{\partial p_{t}}\left[\frac{\sigma-1}{\sigma}\left(1-\tau_{f}\right) p_{i}-\left(1-\tau_{h}\right) c-\left(\tau_{h}-\tau_{f}\right) p_{t}-\lambda\left(p_{a}-p_{t}\right)^{2} q_{f}\right]-} \\
& \\
& \quad-\left(\tau_{h}-\tau_{f}\right) q_{f}+\lambda\left(p_{a}-p_{t}\right) q_{f}^{2}=0
\end{aligned}
$$

After some algebra we derive the following relationship between the transfer price and the arm's length export price chosen by the MNC: ${ }^{22}$

$$
p_{t}-p_{a}=\frac{-\left(\tau_{h}-\tau_{f}\right)}{\lambda q_{i}}
$$

Equation (14) shows that for exports to low tax countries, i.e., $\tau_{h}>\tau_{f}$, the parent firm sets the transfer price below the arm's length price. The tax wedge $\Delta \tau \equiv \tau_{h}-\tau_{f}$ directly increases the magnitude of the gap between the transfer price and the arm's length export price. However, the indirect effect of $\Delta \tau$ through $q_{f}$ cannot be explicitly solved.

As noted in Bernard, Jensen, and Schott (2006), this model does not lend itself to explicit solutions for the endogenous variables $p_{f}^{*}, p_{a}, p_{t}, p_{i}, q_{f}$, and $q_{a}$. However, the system of price equations given by (5), (11), (13), (12), together with the two demand equations $q_{a}\left(p_{a} ; \sigma\right)$ and $q_{f}\left(p_{f} ; \sigma\right)$, are readily solvable numerically. Bernard, Jensen, and Schott (2006) show in their appendix the

\footnotetext{
${ }^{20}$ IRS $\S 482-4.61 .3 .6$ states that "the search for a comparable should begin with a review of the taxpayers operations. The taxpayer may have engaged in uncontrolled transactions potentially comparable to the controlled transactions. This type of comparable is known as an internal comparable."

${ }^{21}$ This penalty function is consistent with the IRS 6662(e) penalty structure, which applies heftier penalties for "substantial or gross misstatements of valuation."

${ }^{22}$ To solve for the transfer price $p_{t}$ from equation (13), note that the first term inside the square brackets can be substituted for using equation (5), while the remaining terms in the square brackets can be substituted for using equation (12). Upon making these changes, the first line of equation (13) becomes zero, leading to equation (14).
} 
results using linear demands while we show in Figure 1 the results using CES demands.

As seen in Figure 1, the direct relationship between the tax wedge and the price gap shown in equation (14) holds true for a wide range of $\Delta \tau \cdot{ }^{23}$ We do not see a price ranking reversal due to the indirect effect of $\Delta \tau$ through $q_{i}$. Figure 1 shows that as the tax wedge increases, the MNC will increase the price gap between its transfer price and its corresponding arm's length export price in order to reduce its global tax burden. This result is well known in the literature on transfer pricing. Most of the empirical analyses to date focus on the price gap $\left(p_{t}-p_{a}\right)$ to examine the effect of foreign corporate tax rates on transfer pricing. This price gap is consistent with the sort of price disparities examined by tax authorities. As such, it has been the focus of the existing literature on transfer pricing. ${ }^{24}$

\section{Manipulations in both Arm's Length and Transfer Prices}

We now come to the crux of this study's contribution: the price gap $\left(p_{t}-p_{a}\right)$ examined by the tax authorities and by the existing literature underestimates the true extent of transfer price manipulations. When facing a penalty for profit shifting via transfer prices, the MNC opts to re-optimize its arm's length price $p_{a}$ to mitigate this penalty. The price $p_{a}$ will now differ from the true reference price $p_{x}$ given by equation (1), which is the price a pure exporter identical to the MNC would charge an unrelated party. ${ }^{25}$ So, to obtain an unbiased measure of the total income shifted by transfer pricing, we need to estimate the difference $\left(p_{t}-p_{x}\right)$, which incorporates the price wedge $\left(p_{a}-p_{x}\right) \cdot{ }^{26}$

Both the arm's length price and the transfer price of the MNC differ systematically from $p_{x}$, and the difference grows with $\Delta \tau$. To show this, first we combine (14) and (11) to find the arm's length export price $p_{a}$ :

\footnotetext{
${ }^{23}$ For exposition purposes, we assume $\Delta \tau \equiv \tau_{h}-\tau_{f} \in[0,30 \%]$. Given a $30 \%$ home tax rate $\tau_{h}$, which reflects the average Danish tax rate for our sample period, the range considered for $\Delta \tau$ covers an extensive set of values for $\tau_{f}$.

${ }^{24}$ See footnote 19 for examples.

${ }^{25}$ Tax authorities recognize the potential to manipulate arm's length prices to hide corresponding manipulations of transfer prices. To account for this, IRS $\S 1.482-1(d)(4)(i i i)$ suggests that an MNC's transaction with an uncontrolled third party should be disregarded as a CUP if "one of the principal purposes of the uncontrolled transaction was to establish an arm's length result with respect to the controlled transaction." In practice, however, demonstrating that $p_{a}$ was manipulated is a difficult task for tax authorities. Our theory posits that $p_{a}$ is always manipulated, and so should never be used as a CUP.

${ }^{26}$ As we will show below, the MNC will charge prices equal to the the fair market value price $p_{x}$ in the absence of any tax related incentives to shift profits abroad (i.e., when $\tau_{f}=\tau_{h}$ ).
} 


$$
\begin{aligned}
p_{a}=p_{x} & \frac{1}{1+\kappa(\Delta \tau)} \\
& \text { where } \kappa(\Delta \tau) \equiv \frac{\Delta \tau}{\left(1-\tau_{h}\right)(\sigma-1)}\left(\frac{q_{f}}{q_{a}}\right)
\end{aligned}
$$

Equation (15) shows that $p_{a}$ differs from $p_{x}$ by a fraction $\frac{1}{1+\kappa(\Delta \tau)}$, which depends on the tax wedge $\Delta \tau$, among others. Importantly, note that $\kappa(\Delta \tau)$ is increasing in, and has the same sign as $\Delta \tau{ }^{27}$

Similarly, the transfer price $p_{t}$ can be derived as:

$$
p_{t}=p_{x} \cdot \frac{1}{1+\kappa(\Delta \tau)}-\frac{\Delta \tau}{\lambda q_{f}}
$$

which shows that the difference between $p_{t}$ and the true reference price $p_{x}$ is also dependent on the tax wedge. Importantly, note that when the tax wedge is equal to zero, i.e., $\tau_{h}=\tau_{f}$, then the MNC has no incentives to manipulate its export prices, and both $p_{t}$ and $p_{a}$ are exactly equal to the true CUP, $p_{x}$ :

$$
\tau_{h}=\tau_{f} \Rightarrow p_{t}=p_{a}=p_{x}
$$

When faced with different tax rates between the headquarter country and the destination country, the MNC will skew both the arm's length price and the transfer price for exports to that destination. To measure the extent to which the differential tax rates influence the export prices of an MNC, we must measure the difference between the transfer price $p_{t}$ and the true reference price $p_{x}$ posted in the absence of income shifting incentives. This price difference is given by:

$$
p_{t}-p_{x}=-\left[\left(\frac{\sigma}{\sigma-1} c\right) \cdot \frac{\kappa(\Delta \tau)}{1+\kappa(\Delta \tau)}+\frac{\Delta \tau}{\lambda q_{i}}\right]
$$

Note that the term in the square bracket has the same sign as $\Delta \tau$. When the home country has a higher tax rate than the foreign country (i.e., $\Delta \tau>0$ ), the multinational firm prices its affiliated exports below the true reference price in order to transfer income abroad and reduce its tax burden.

Likewise, the difference between $p_{a}$ and $p_{x}$ can be calculated as:

$$
p_{a}-p_{x}=-\left(\frac{\sigma}{\sigma-1} c\right) \cdot \frac{\kappa(\Delta \tau)}{1+\kappa(\Delta \tau)}
$$

\footnotetext{
${ }^{27}$ We could not explicitly sign the derivative $\frac{d \kappa}{d \Delta \tau}$ due to the nonexplicit nature of $\frac{q_{f}}{q_{a}}$. However, Figure 2 shows that $\frac{d \kappa}{d(\Delta \tau)}$ is positive for the range of $\Delta \tau$ in our sample.
} 
The negative sign in front of the two positive terms implies that when $\Delta \tau>0$, i.e., the home country has a higher tax rate than the foreign country, the firm will lower its arm's length price charged to independent parties to a value below the true reference price (i.e., true CUP).

Since both the transfer price and the arm's length price are affected by the tax wedge $\Delta \tau$, the price gap $p_{t}-p_{a}$ in equation (14) understates the extent of transfer price manipulations, which is in fact given by $p_{t}-p_{x}$. This can be seen in Figure 1, where $p_{t}$ is always below $p_{a}$, which is always below $p_{x}$. By estimating equation (14), the existing literature implicitly assumes that the arm's length price $p_{a}$ is equal to the true reference CUP, $p_{x}$, underestimating the full extent of transfer price manipulations.

An implication of our analysis is that MNCs, in addition to shifting income to their foreign affiliates via their transfer pricing strategies, also shift income to foreign unrelated parties via their arms length pricing, $p_{a}$. This is a tradeoff that the MNCs have to incur in order to take advantage of the tax savings obtained from transfer pricing. However, this further reduces the income reported to the home tax authorities and the MNCs' global tax burden. So, in order to measure the total income shifted by MNCs to foreign shores, we need to consider the effect of tax rate differences on both price gaps: $\left(p_{t}-p_{x}\right)$ and $\left(p_{a}-p_{x}\right)$.

\section{From Theoretical Prices to Observed Unit Values}

The prior section discussed the theoretical pricing of exports. In reality, customs data only report the total value and total weight of a shipment. From these data, econometricians observe only the unit value of an international shipment. In addition, most observed export transactions do not include information on the affiliation of the importing entity. This is the case for our micro dataset as well. So, an MNC that exports a good to both affiliated and unrelated third parties is going to be observed in our transaction dataset as charging an export unit value that is a weighted average of the (intra-firm) transfer price $p_{t}$ and the arm's length export price $p_{a}$. For consistency with our empirical analysis, we define the observable $\mathrm{MNC}$ export unit value $p_{m}$ as:

$$
p_{m}=s_{f} p_{t}+\left(1-s_{f}\right) p_{a}, \quad \text { with } \quad s_{f} \equiv \frac{q_{f}}{q_{f}+q_{a}}
$$

The behavior of $p_{m}$ is graphed in Figure 1. Predicting the behavior of $p_{m}$ is made easier by the fact that both $p_{a}$ and $p_{x}$ respond in the same direction, although to a different extent, to 
differences in corporate tax rates across locations. So, we can show theoretically that the difference $p_{m}-p_{x}$ increases with the tax wedge. Formally:

$$
p_{m}-p_{x}=-\left(\frac{\kappa(\Delta \tau)}{1+\kappa(\Delta \tau)} \cdot p_{x}+\frac{\Delta \tau}{\lambda\left(q_{a}+q_{f}\right)}\right)
$$

The size of this unit value gap is sufficient to determine the total income shifted by the MNC, both to related and to unrelated parties, in an attempt to reduce its global tax burden. To see this, notice that the export revenue underreported by the MNC to the home government when trading with a low tax regime country is given by:

$$
\begin{aligned}
\text { LostExpRev } & =\left(p_{t}-p_{x}\right) q_{a}+\left(p_{t}-p_{x}\right) q_{f} \\
& =\left(p_{a} \frac{q_{a}}{q_{a}+q_{f}}+p_{f} \frac{q_{f}}{q_{a}+q_{f}}\right)\left(q_{a}+q_{f}\right)-p_{x}\left(q_{a}+q_{f}\right) \\
& =\left(p_{m}-p_{x}\right)\left(q_{a}+q_{f}\right)
\end{aligned}
$$

This result shows the importance of measuring with precision the difference $p_{m}-p_{x}$. Examination of equation (22) and of the corresponding Figure 1 leads to the following key implication.

\section{Hypothesis 1:}

Differences in corporate tax rates across countries determine multinational corporations to set export unit values that are lower(higher) than the true reference prices (i.e., true CUPs) as a result of income shifting to low(high) tax countries. Formally:

1. For $\Delta \tau>0 \Rightarrow p_{x}>p_{a}>p_{t}$, which implies that $p_{m}-p_{x}<0$.

For $\Delta \tau<0 \Rightarrow p_{x}<p_{a}<p_{t}$, which implies that $p_{m}-p_{x}>0$.

2. $\frac{d\left|p_{m}-p_{x}\right|}{d|\Delta \tau|}<0$

The main prediction derived from the theory is that a multinational firm facing different corporate tax rates in the home and foreign markets will manipulate its intra-firm and arm's length export prices in order to shift income away from the high tax regime locations. This strategic behavior will affect the MNC's export unit value in the following manner: the price gap $\left(p_{m}-p_{x}\right)$ between the export unit value of the MNC and that of a comparable pure exporter will have the opposite sign as the tax wedge $\Delta \tau$ between the home and foreign countries. Further, the magnitude

of this price gap increases with the magnitude of the tax wedge. That is, $\frac{d\left|p_{m}-p_{x}\right|}{d\left|\Delta \tau_{j}\right|}<0$. 
Prior studies have examined the relationship between the tax wedge $\Delta \tau$, and the price gap $\left(p_{t}-p_{a}\right)$, calculated based on contemporaneous intra-firm and arm's length trade transactions. ${ }^{28}$ What we have shown is that the price gap $\left(p_{t}-p_{a}\right)$ is an incomplete and understated measure of the degree of income shifting undertaken by MNCs. Researchers and tax authorities should instead measure the gap $\left(p_{m}-p_{x}\right)$. However, an empirical challenge with this metric is that the true CUP, $p_{x}$, is not directly observable for active MNCs. So we cannot directly calculate the difference between $p_{m}$ and $p_{x}$. Instead, we need to infer from the data what export price an MNC would have charged a third party, had it behaved as a pure exporter unaffected by tax savings incentives (i.e., the true CUP, $\left.p_{x}\right)$. This study does it by employing a difference-in-difference-in-differences (DDD) estimation method described in detail below.

\section{Estimation Strategy}

The prior section provided predictions about the price gap $\left(p_{m}-p_{x}\right)$ between the observed export unit value of a multinational firm and the price that the MNC would have charged absent any incentives to minimize the tax burden by shifting profits across locations. However, this price gap is difficult to calculate since the true reference CUP, $p_{x}$, is not directly observable for any active MNC. To overcome this challenge, we exploit information on the unit values of non-MNC firms that export the same product to the same destination across multiple years. An important aspect to consider is the systematic difference between MNC and pure-exporters in the way they set export prices and respond to market-specific shocks. To strip away these additional layers of heterogeneity, we use a difference-in-difference-in-differences ("DDD") methodology. The next subsection presents this DDD methodology. The subsection after discusses how we implement it in the data, while controlling for the various idiosyncrasies in our sample.

\subsection{A difference-in-difference-in-differences methodology for export prices}

In this subsection, we step through our DDD methodology to show how triple differencing the data allows us to correctly identify the extent of transfer price manipulations, in accordance with the predictions of Hypothesis 1. The strategy is to estimate the average change in the export price

\footnotetext{
${ }^{28}$ See, among others, Clausing (2003) and Bernard, Jensen, and Schott (2006).
} 
of a product resulting from the change in foreign firm ownership (first treatment), differentiating between destination countries based on the level of their corporate tax rates relative to the tax rate of the home country (second treatment).

We consider the export of a product to a low tax regime country $j$ in two years $y \in\{1,2\}$ by two types of firms: one of them, indexed by $x$, belongs to the control group of pure exporters, who only trade in the destination market $j$ with unaffiliated parties; the other one, indexed by $m$, is part of the treatment group of 'emerging' MNCs, who set up their first affiliate in country $j$ between years 1 and 2 . In each time period we observe the export unit values of the pure exporter, $p_{x}^{j y}$, as well as the export unit values of the emerging MNC, i.e., $p_{m}^{j y}$. The evolution of these unit values over the two years is illustrated by the solid lines in Figure 3.

We characterize the observed unit value of the pure exporter $x$ as follows:

$$
p_{x}^{j y} \equiv p_{x}+\alpha_{x}+\alpha^{j y}, \quad y \in\{1,2\}
$$

where $p_{x}$ denotes the true CUP of a representative exporter, determined as in equation (1). Because export unit values differ across firms and across foreign markets for numerous reasons, including differences in technology or foreign market competition, we let $\alpha_{x}$ account for any firm characteristics unique to the pure exporter, and we let $\alpha^{j y}$ capture all the unobservable time-specific heterogeneities characterizing the foreign market $j$.

We define the observed unit values of an emerging MNC in a similar way, but write them separately for years 1 and 2 because of the change in the foreign firm ownership. Thus:

$$
\begin{aligned}
& p_{m}^{j 1} \equiv p_{x}+\alpha_{m}+\alpha^{j 1} \\
& p_{m}^{j 2} \equiv p_{m}+\delta+\alpha_{m}+\alpha^{j 2}
\end{aligned}
$$

In the first period, the emerging MNC does not own an affiliate in the foreign market, so its behavior mirrors that of a pure exporter. It posts the same true reference export price, $p_{x}$, adjusted to accommodate for latent firm specific effects, $\alpha_{m}$, as well as destination-year fixed effects, $\alpha^{j y}$.

Between the two periods, firm $m$ acquires an affiliate in foreign country $j$. This act changes the observed export unit value $p_{m}^{j 2}$ in two ways. First, as our theory predicts, there is a deviation in the valuation of the good from the true exporter price, $p_{x}$, to a new tax-incentivized unit value, 
$p_{m}$, defined in equation (21). Second, there may be an additional price effect influencing the export transactions of an MNC, that is determined by the expansion of the firm's activity through the establishment of a foreign affiliate. This additional price effect is captured by $\delta$ in equation (26), and is considered to be orthogonal to the difference in corporate tax rates across locations. ${ }^{29}$

To test Hypothesis 1, we must estimate the difference between $p_{m}$ and $p_{x}$. Given the export unit values observable in the dataset, one candidate is the difference $\left(p_{m}^{j 2}-p_{x}^{j 2}\right)$ between the MNC and the pure-exporter selling the same product to the same low tax country $j$ :

$$
\text { [First Difference]: } \quad p_{m}^{j 2}-p_{x}^{j 2}=\left(p_{m}-p_{x}\right)+\delta+\alpha_{m}-\alpha_{x}
$$

However, as this equation shows, the difference $\left(p_{m}^{j 2}-p_{x}^{j 2}\right)$ does not only reflect the MNC's response to the tax rate difference across countries (i.e., $p_{m}-p_{x}$ ), but also the unobserved heterogeneities in firm characteristics (i.e., $\alpha_{m}-\alpha_{x}$ ), or ownership status (i.e., $\delta$ ) that affect the unit values. These heterogeneities bias our estimates. The purpose of our triple-difference methodology is to net out these heterogeneities in order to isolate $\left(p_{m}-p_{x}\right)$.

To infer what fraction of the observed price gap is due to systematic differences across firms, we exploit information from the first period export unit values, i.e., equations (24) and (25):

$$
p_{m}^{j 1}-p_{x}^{j 1}=\alpha_{m}-\alpha_{x}
$$

An essential insight in deriving this result is the fact that the emerging MNC, in the absence of a foreign affiliate in a market with a different tax rate than the home country, posts the same base price $p_{x}$ as that of a pure exporter with identical firm characteristics. This means that the observable price disparity is the result of systematic differences in firm characteristics. Referring to Figure 3, this difference $\left(\alpha_{m}-\alpha_{x}\right)$ is illustrated by ' $\varphi$ '. It accounts for any unobservable heterogeneities in firm-specific attributes such as production technology, cost structure or market power, that have a direct effect on the level of export prices.

\footnotetext{
${ }^{29}$ For example, the firm could move the final stages of of packaging from the headquarters to the affiliate. Since production fragmentation happens irrespective of the corporate tax rate in the foreign market, the parameter $\delta$ would automatically capture these effects. All the systematic price changes that are associated with the establishment a new plant in a foreign market and which are not caused by transfer pricing manipulations should be captured by $\delta$.
} 
Subtracting equation (28) from equation (27), we get:

$$
\text { [Double Difference]: } \quad \Lambda_{j} \equiv\left(p_{m}^{j 2}-p_{x}^{j 2}\right)-\left(p_{m}^{j 1}-p_{x}^{j 1}\right)=\left(p_{m}-p_{x}\right)+\delta
$$

where $\Lambda_{j}$ captures the effect that the establishment of a foreign affiliate in country $j$ has on the export prices to that destination. Note that $\Lambda_{j}$ is market specific because the export price $p_{m}$ is chosen based on the tax regime of the destination country. However, if $\Lambda_{j}=\Lambda$ for $\forall j$, then $\Lambda$ would correspond to the standard difference-in-difference estimator. Referring to Figure 3 again, the price difference in equation (29) is illustrated by ' $\Lambda_{j}$ '.

A preliminary look at the data gives support to such a systematic change in export prices. Figure 4 illustrates the average unit value of a product exported by an MNC both before and after establishing foreign ownership in a destination country with a lower tax rate than the home country. The MNC export unit value is expressed relative to the unit value of a pure exporter firm. Relevant for us, the observed direction of change in the MNC export price post-acquisition seems to be correlated with the corporate tax difference between the home and foreign countries in a way that is consistent with equation (29). What remains to be shown is whether tax avoidance is the reason behind the observed price difference.

The theory section shows that in the absence of profit shifting incentives via transfer price manipulations, the MNC export price $p_{m}$ would be equal to the true CUP $p_{x}$. Referring to equation (29), this implies that the price effect associated with the foreign firm ownership would boil down to $\delta$, being common across all destination countries irrespective of their tax regimes. However, this only happens when $\Delta \tau_{j}=0$. Otherwise, $\left(p_{m}-p_{x}\right)$ varies with the difference in corporate tax rates $\Delta \tau_{j}$ between the home and foreign countries (as suggested by equation (22) in the theory). We approximate this direct relationship between the export prices and corporate tax rates across markets as linear in the tax wedge:

$$
p_{m}-p_{x} \equiv \beta \cdot \Delta \tau_{j}
$$

$\beta$ is a parameter that captures the responsiveness of an MNC's export price to differences in corporate tax rates, relative to a pure exporter's price. Given this predicted relation, we can rewrite $\Lambda_{j}$ from equation (29) as follows: 


$$
\Lambda_{j}=\beta \cdot \Delta \tau_{j}+\delta
$$

Variation in corporate tax rates across countries allows us to identify the slope parameter $\beta$ separately from the acquisition effect $\delta$. To be specific, by observing $\Lambda_{j^{\prime}}$ for another low tax country $j^{\prime}$ for which $\Delta \tau_{j} \neq \Delta \tau_{j^{\prime}}$, we can infer $\beta$ by taking the difference between the two differencein-difference estimators:

$$
\text { [Triple Difference]: } \quad \Lambda_{j}-\Lambda_{j^{\prime}}=\beta \cdot\left(\Delta \tau_{j}-\Delta \tau_{j^{\prime}}\right)
$$

Equation (32) defines our triple difference estimator. Since all the terms on the left hand side are directly observable, it is straightforward to estimate $\beta$. If $\beta=0$, then the tax rates do not affect the export unit values of MNCs, and the difference-in-difference estimator $\Lambda_{j}=\delta$ is sufficient to capture the price effects associated with the establishment of a foreign affiliate. However, the hypothesis derived from our theory predicts that the tax regime does affect the export prices chosen by an MNC. Based on the prediction of Hypothesis 1.1, $\beta$ is expected to be less than zero. Thus, the test of our model is whether the triple difference estimator is significantly negative. ${ }^{30}$

\subsection{Implementing the triple difference methodology using the trade data}

To implement our DDD methodology using micro level trade data, we start from a standard difference-in-difference estimation equation that captures the effect of a change in the foreign firm ownership on the export unit values of traded goods. We then amend the model to incorporate the triple difference term exploiting the variation in the corporate tax rates across countries.

In this process, an important aspect to consider is the dimensionality of the trade dataset, and its many levels of heterogeneity. Our panel spans four dimensions - firm, product, country and time - but for our empirical analysis we reduce in to two dimensions. We define a unit of observation as a trade transaction by firm $i$ to country $j$ in product $k$, and evaluate the effects of our two treatments - changes in foreign firm ownership and changes in foreign corporate tax rates - on the observed export unit values.

We consider the observed export unit value $p_{i j k t}$ for a firm $i$ exporting product $k$ to market

\footnotetext{
${ }^{30}$ The discussion of the methodology is conducted with country $j$ assumed to be a low tax regime country. The analysis proceeds in a similarly way for the high tax regime country case, with the prediction that the triple difference estimator is greater than zero.
} 
$j$ at time $t$, and denote by $D A f f_{i j t}$ the indicator variable equal to one if firm $i$ owns a foreign affiliate in country $j$ at time $t$. Before discussing our triple difference estimation, let's begin with a standard Difference-in-Difference specification relating $p_{i j k t}$ to $D A f f_{i j t}$ :

$$
\ln p_{i j k t}=\alpha_{i j k}+\alpha_{t}+\Lambda \cdot D A f f_{i j t}+\theta \cdot X_{i t}+\gamma \cdot X_{j t}+\epsilon_{i j k t} .
$$

In the above equation, $\alpha$ indexes fixed effects: $\alpha_{i j k}$ captures any unobservable, time-invariant price determinant that is specific to a given firm-country-product trade transaction, while $\alpha_{t}$ captures period-specific price shocks. The vectors $X_{i t}$ and $X_{j t}$ represent observable time-varying firm and foreign country control variables, respectively. ${ }^{31} \epsilon$ denotes the error term. The coefficient $\Lambda$ measures the average impact of owning a foreign affiliate on an MNC's export unit values. The DiD specification assumes this impact is constant across destinations.

However, our theory predicts that the impact of owning an affiliate does vary systematically with destination market characteristics. Therefore, a specification consistent with this prediction would replace $\Lambda$ in equation (33) with $\Lambda_{j}$. In addition, Hypothesis 1 predicts that $\Lambda_{j}$ is correlated with the foreign country tax rate, as modeled by Equation (31). Our goal is to estimate this correlation. Substituting $\Lambda_{j}$ from equation (31) into $\Lambda$ in equation (33), and expressing the tax wedge $\Delta \tau_{j}$ in absolute terms as $\left|\Delta \tau_{j t}\right| \times I^{\text {LowTax }}$, with $I^{\text {LowTax }}$ an indicator for low tax regime countries, we derive the following estimation equation:

$$
\ln p_{i j k t}=\alpha_{i j k}+\alpha_{t}+\left[\delta+\beta \cdot\left|\Delta \tau_{j t}\right| \cdot I^{\mathrm{LowTax}}\right] \times \mathrm{DAff}_{i j t}+\theta \cdot X_{i t}+\gamma \cdot X_{j t}+\epsilon_{i j k t}
$$

This equation represents our difference-in-difference-in-differences regression model. The coefficient $\delta$ measures the average price effect associated with establishing an affiliate, while $\beta$ captures the additional price change determined by differences in corporate tax rates across destinations. If the relationship between export unit values and affiliate acquisition were not dependent on the tax regime of country $j$, then adding the tax wedge $\Delta \tau_{j}$ to the regression model would be superfluous.

\footnotetext{
${ }^{31}$ In the estimation, the vector $X_{i t}$ includes information on firm level employment and sales, while the vector $X_{j t}$ includes information on country level population and real per capita GDP, on exchange rates and statutory corporate tax rates. These control variables are important not only because they explain export prices, but also because they influence the decision to establish foreign affiliates. For example, di Giovanni (2005) provides evidence of a significant negative effect of corporate taxes on M\&As, while Desai, Foley, and Hines (2006) finds that large, fast growing MNCs are more likely to set tax haven operations, affecting their potential to shift income and reduce the global tax burden.
} 
However, Hypothesis 1 suggests that the tax regime of a country is a key omitted variable in the export price regression.

Our coefficient of interest is $\beta$. It corresponds exactly to the triple-difference estimator defined by equation (32). The interaction between owning a foreign affiliate and the tax rate difference for low tax regime countries strictly identifies the change in intra-firm export unit values driven by profit shifting motives. Thus, $\beta$ reveals the firm's transfer pricing behavior.

For consistency with the theory and the empirical methodology, we expand the regression model in two ways. First, we add another interaction term to capture the effect of owning an affiliate in a foreign country that has a higher corporate tax rate than the home market. Although the theory framework does not suggest a differential price response for a change in the absolute tax wedge $\left|\Delta \tau_{j t}\right|$ based on the tax regime of the foreign country (i.e., whether country $j$ has a higher tax rate or lower tax rate compared to the home market), we nevertheless allow for such asymmetries in our estimation model. ${ }^{32}$

Second, we allow the year fixed effects $\alpha_{t}$ to vary by the tax regime of the foreign country. Thus, we denote by $\left(\alpha_{t, \text { LowTax }}\right)$ and $\left(\alpha_{t, \text { HighTax }}\right)$ the interaction terms between the year fixed effects and the corresponding tax regime indicators. In adding these differential time effects, we aim to control for unobservable time-varying factors that affect export prices and may be specific to the group of countries that set higher, respectively lower tax rates. ${ }^{33}$

With these additional control variables, after rearranging, our regression model becomes:

$$
\begin{aligned}
\ln p_{i j k t}=\alpha_{i j k}+\alpha_{t}+\delta \cdot \operatorname{DAff}_{i j t} & +\left[\beta_{1} \cdot I^{\text {LowTax }}+\beta_{2} \cdot I^{\text {HighTax }}\right] \times\left|\Delta \tau_{j t}\right| \times \text { DAff }_{i j t}+ \\
& +\theta \cdot X_{i t}+\gamma \cdot X_{j t}+\alpha_{t, \text { LowTax }}+\alpha_{t, \text { HighTax }}+\epsilon_{i j k t}
\end{aligned}
$$

This represents the estimation equation that we take to the data. To account for possible correlations in export prices among all the Danish firms trading with the same foreign market, we cluster the standard errors by country-year pairs.

\footnotetext{
${ }^{32}$ Asymmetries in MNCs' responses to corporate tax rate differences may be explained, for example, by the unequal efforts of the home country tax authorities to inspect and detect transfer pricing in transactions with high tax countries, relative to low tax countries. At the same time, it could be the case that governments in high tax countries may have on average a stronger tax enforcement power, deterring Danish MNCs from engaging in transfer pricing.

${ }^{33}$ These regime specific time effect represent a closer approximation to the country-year fixed effects from the price equation (24)-(26).
} 


\section{Data}

To estimate our model, we employ micro level data from Denmark. We combine two data sources on Danish firms, one providing information on all international trade transactions, and the other on firms' ownership of foreign assets.

Our firm level data comes from the administrative records maintained by Statistics Denmark. The Firm Statistics Register covers the universe of private sector Danish firms, with each firm identified by a unique numeric code to facilitate drawing information on firm characteristics and activities from multiple administrative registries. For each firm we observe the employment size and level of sales, the industry affiliation (eight digit NACE code) for all its productive activities, and all the international transactions reported in customs statistics.

For the estimations in this paper, we only focus on the sample of manufacturing exporters operating during the time period 1999-2006. Based on the information on annual exports recorded by value and by weight for each product code and foreign destination market, we determine the average unit values by dividing export values by the quantities shipped at the firm-product-destination level of detail. In constructing the sample, we drop the observations with negative or missing export values, or for which we cannot measure unit values because of zero or missing weight values. ${ }^{34} \mathrm{We}$ further drop the top and bottom 1 percent of prices to eliminate measurement or keying errors.

To obtain information on foreign direct investments (FDI) involving Danish firms, we use data on foreign firm ownership shares provided by Experian. Experian collects firm level information on foreign ownership from the annual reports published by Danish firms, which are supplemented with information from the transaction records maintained by the National Bank of Denmark. ${ }^{35}$ Each firm is reported in the dataset with the same unique numeric firm identifier as employed by Statistics Denmark.

Based on the firm level information available in the Experian database, we construct two indicator variables of foreign ownership. First, we identify the manufacturing firms that operate in Denmark during our sample period and that are foreign owned (i.e., majority shares are owned by foreign nationals). This foreign ownership indicator corresponds to a fraction of the inbound

\footnotetext{
${ }^{34}$ We lose approximately 4 percent of the data because of such data reporting issues.

${ }^{35}$ The firms reported in the database may not cover the entire population of Danish firms undertaking foreign direct investments. Even so, the data provided by Experian is of very high quality, being widely used by research analysts. In fact, this is the primary data source on Danish firms used in Bureau van Dijk's Orbis and Amadeus databases.
} 
FDI activity in Denmark. ${ }^{36}$ In a similar manner, we track Denmark's outward FDI activity by identifying the countries in which a Danish firm holds majority ownership of a local establishment. In the end, the resulting firm level dataset on foreign direct investments reports for each Danish firm information about its foreign ownership status, and its multinational activity, with a complete list of foreign markets in which the firm owns affiliates.

To construct our estimation sample, we merge the firm level information on asset ownership by foreign country with corresponding customs data on export transactions. Important for our purposes, the resulting dataset reports for each manufacturing exporter the unit values of every product shipped to a particular foreign country, and whether the firm owns a foreign affiliate in that country. 37

We do not have information on whether the beneficiary of a particular export transaction is an affiliated party or an unrelated buyer. So, we rely on the expectation that whenever an exporter owns a firm in a foreign market, at least a fraction of the observed export shipments must be intrafirm. This means that the unit value observed in foreign markets where the firms owns a foreign affiliate represents a weighted average of intra-firm and arm's length prices. This is important for interpreting the results from our estimation exercises.

We augment the Danish firm level dataset with foreign country level information on population, per-capita GDP, real exchange rate and statutory corporate tax rate. All the country level variables are taken from the Penn World Tables version 3.0. except for the corporate tax information, which is collected from the OECD Tax Database and, for non-OECD countries, from the World Tax Database provided by the Office of Tax Policy Research at the University of Michigan. We use the statutory corporate tax rates to compute the difference in absolute value between the tax rate of a foreign country and that of Denmark. In doing so, we track the countries with tax rates above or below Denmark's rate by creating indicator variables equal to one if a country has High Tax, respectively Low Tax.

To summarize the tax rate dynamics present in our data, Figure 5 illustrates the time trend

\footnotetext{
${ }^{36}$ FDI statistics are defined based on a minimum threshold of 10 percent ownership share. By disregarding foreign investment activities that fall short of the 50 percent majority ownership break point, our indicator measure of foreign ownership underestimates the volume of inbound FDI. The same comment applies to outbound FDI, given our interest in majority-owned foreign affiliates of Danish multinational firms.

${ }^{37}$ For all the firms that establish a foreign affiliate during the sample period, we remove the observation corresponding to the actual year of acquisition. This is done in order to mitigate measurement error in export unit values. This way we can be sure that when $D A f f=1(D A f f=0)$, the pricing strategy of the Danish exporter is characterized 100 percent by its MNC (exporter-only) status.
} 
for the Danish corporate tax rate in comparison to the level of taxes in several top export destination markets. Figure 6 provides a histogram of the corporate tax rate difference between Denmark and its foreign trade partner. Both data plots convey a similar message: the level of the Danish statutory corporate tax rate is conservative, as there are important trade partners that charge significantly higher, or significantly lower tax rates. The dispersion in the foreign corporate tax rates relative to the level in Denmark is very useful for our estimation exercises, as it provides significant variation to the constructed tax wedge variable.

To conclude the discussion on the data sources and sample construction, Table 1 provides the summary statistics for the variables in our final dataset. A unit of observation is a firm-productcountry-year quadruplet. Trade transactions carried by Danish multinationals in foreign markets where they have majority owned affiliates represent 11.4 percent of all observations. Almost 3 percent of all trade transactions correspond to Danish multinationals that establish their first majority owned affiliate in a country during our sample period. Even though the number of export transactions handled by Danish multinationals is not large by count, in value terms they account for a significant fraction of total Danish exports. Table 2 provides evidence in support of this. The reported summary statistics are constructed by year at firm-country level in order to illustrate the exceptional growth and export performance of Danish multinationals in countries where they establish foreign ownership.

\section{$5 \quad$ Estimation Results}

In this section we examine the extent to which Danish multinational firms shift profits to low tax locations via transfer price manipulations. In estimating the regression model given by equation (35), we exploit a novel source of variation: the establishment of new foreign affiliates by Danish multinationals in countries where they have previously exported. This allows us to investigate whether the changes in the product level export prices determined by new foreign firm ownerships are systematically related to difference in corporate tax rates across countries. Throughout our analysis, we treat firms' foreign direct investment decisions as orthogonal to pricing decisions, especially once we condition on all the firm and country characteristics. ${ }^{38}$

\footnotetext{
${ }^{38}$ In this paper, we do not consider the ability to shift profits via transfer price manipulations a determining factor in investment location decisions, but rather an opportunistic behavior consequent to investments already made. This
} 


\subsection{Baseline Specification}

Table 3 reports the effects of the corporate tax wedge on the unit value of a multinational's exports to a low/high tax destination, after controlling for all the relevant dimensions of data heterogeneity that may affect the estimates. Overall, we find significant evidence that firms lower the unit value of exports to low tax countries where they own affiliates. As column 1 shows, a 10 percentage point decrease in the corporate tax rate of a low tax country corresponds to a 5.7 percent decrease in the export unit value of an MNC, relative to a pure exporter shipping the same product to that market. This result is consistent with our theory that Danish multinationals undervalue their exports to low tax countries in order to transfer profits and avoid taxation. We also find evidence that multinational firms price their exports higher in high tax countries where they own an affiliate, by comparison to pure exporters. However, the results are statistically insignificant. Later, we will show subsamples where this difference becomes weakly significant.

The results reported in column 1 of Table 3 could be biased by two sources of endogeneity. First, Danish firms that own affiliates in foreign countries could also themselves be affiliates of a foreign multinational firm. It may be that Danish firms owned by foreign multinationals make different transaction decisions than their domestic counterparts, particularly because of their involvement in the tax avoidance strategies decided by their parent firms. Second, our estimation exploits the data variation generated at the time when a firm establishes an affiliate in a foreign country. If the firm sets up the foreign affiliate in response to a decline in export prices in low tax countries, then this generates ambiguity in the direction of causation between acquisition and fallings prices.

We address these two issues in columns 2 and 3 of Table 3. We add a control dummy variable indicating the foreign ownership of the Danish firm, and a pre-MNC indicator controlling for the price of that firm-product-destination export transaction in the year prior to the establishment of a foreign affiliate. As the results in column 2 show, foreign ownership has no statistically significant

is because, for one, taxation policy can change quite frequently, making this source of income savings highly uncertain in the future. Furthermore, multinational firms exploit a variety of mechanisms to minimize their global tax burden, so setting up affiliates that undertake real activity may not necessarily be the most cost-effective option. In the end, even if transfer pricing were to be a determinant of investment locations, then the production and transfer of intangibles must weigh in more heavily in this decision (i.e., higher valued transactions with lower risk of detection). Consistent with these explanations, the evidence in Blonigen and Piger (2012) suggest that foreign plant acquisitions are insensitive to host country tax rates. 
effect on export unit values. The same can be inferred from the estimates reported in column 3 . They suggest that there is no systematic variation in unit values the year prior to the establishment of a foreign affiliate. If anything, the unit values of exports to low tax countries set by emerging multinational firms actually increases slightly the year before this change of status, relative to pure exporters.

In identifying MNCs' pricing behavior, we exploit two sources of data variation. The first comes from changes in the countries' corporate tax rates relative to Denmark's tax rate. The second comes from the switch of an exporter-only firm into a multinational firm through the establishment of a foreign affiliate. To separately exploit each source of data variation, we examine the price effects from two distinct subsets of our treatment group. The results are summarized in Table 4.

For the first subsample, we select those firms who establish a foreign affiliate sometime during our sample period, and drop all their export transactions that occurred prior to the foreign firm ownership. That is, we only keep firm-product-country exporting spells that are entirely attributed to pure exporters or to multinational firms. Our only source of data variation and coefficient identification comes solely from changes in the tax wedge. Since any Danish firm in our sample is too small at the international level to influence foreign governments into changing their corporate tax rates, this variation is entirely exogenous to the firm's behavior. That is, a country's tax policy is taken as given by each multinational corporation making intra-firm trade decisions. As Table 4 column 1 reports, our main results hold true even when using this restricted sample: multinationals selling to a low tax country will reduce the unit value of their exports by 6.36 percent in response to a 10 percentage point drop in that country's tax rate.

A potential concern with exploiting this source of data variation is the possibility of sluggish adjustments in transfer prices to changes in foreign tax rates. Multinational firms with continuously owned foreign affiliates have a history of transfer prices that can be used by tax authorities towards detecting profit shifting motives whenever there is a simultaneous change in transfer prices and foreign corporate tax rates. This may attenuate a firm's price response to a change in foreign corporate tax rates. As a result, profit shifting may happen much more gradually over time. Because of this consideration, we investigate the performance of our model on a sample of expanding multinational firms.

For our second subsample, we remove from the estimation the export transactions by multi- 
national firms that own affiliates in a given location for the entire sample period, and thus are never observed acting as pure exporters at any point during in time. By doing so, we essentially eliminate the data variation within a firm-product-country triplet that comes solely from movements in the tax wedge. ${ }^{39}$ The resulting estimates are stronger. Table 4 column 2 shows an increase in the price elasticity: a 10 percentage point decrease in a country's tax rate relative to Denmark's rate corresponds to an 8.24 percent decrease in the unit value of affiliated exports. The results are even more pronounced when we restrict the treatment group to only those multinationals that establish a new affiliate, and thus remove the variation coming from closing down or selling an affiliate. Table 4 column 3 shows that for those multinationals that establish an affiliate in a low tax country, a 10 percentage point decrease in the tax rate relative to Denmark's corresponds to a 9.13 percent decrease in the export unit value. For this subsample, the tax wedge in the high tax countries also influences significantly the average unit value of exports: a 10 percentage point increase in the rate of a high tax country relative to Denmark's corresponds to a 12.6 percent increase in the unit value of exports by multinationals.

Non-measureable product characteristics can also determine the extent to which a firm can shift profits overseas. For commodities sold on organized exchanges, or for products that have a reference price, MNCs have a more difficult time justifying price differences to the tax authorities. By contrast, prices of differentiated goods can more easily hide profit shifting under the guise of product complexity or quality differentiation. To test this, we restrict the sample to products classified as "differentiated" based on the liberal classification proposed by Rauch (1999). As observed from the results reported in Table 5, price manipulation is more pronounced among differentiated goods. This finding is consistent across the subsamples previously considered in Table 4. The estimates reported in column 1 suggest that a 10 percentage point increase in the tax wedge determines MNCs owning foreign affiliates in low corporate tax countries to export their goods at unit values 6.48 percent below the arm's length unit values charged by comparable exporters. While not statistically significant, a 10 percentage point increase in the tax rate difference for high tax countries corresponds to a 4.09 percent increase in the unit value of exports by multinationals. These effects are much larger when estimated on the subsample of newly established affiliates.

\footnotetext{
${ }^{39}$ One advantage in exploiting changes in foreign firm ownership is that it allows us to observe firms making transfer price decisions in a new environment that is not constrained by prior intra-firm transactions. We believe that such a scenario gives MNCs more bargaining power in defending their pricing strategies, potentially leading to larger estimates.
} 


\subsection{Robustness Exercises}

To ensure the robustness of our results, we verify the stability of our estimates to: 1) various sub-samples, 2) a narrower re-definition of the "treatment" group, and 3) possible non-linearities in the main effect.

The first data cut considers the existence of a double taxation agreement (DTT) between Denmark and each foreign country in the sample. These DTTs allow firms to credit foreign taxes against their domestic tax bill. In theory, they would encourage firms to shift more income. On the other hand, DTTs typically involve increased cooperation among partner countries in detecting and penalizing tax evasion, and this may refrain MNCs from using transfer pricing as a method to shift profits.

Table 6 reports the estimation results from this sample cut. For comparison purposes column 1 reproduces the baseline coefficients from Table 3 obtained from all goods trade data, and column 2 reproduces the coefficients from Table 5 based on the differentiated goods subsample. Columns 3 and 4 report the estimates from the double taxation agreement sub-sample using export transactions of all goods and of differentiated goods respectively. While the sign and significance pattern is identical across the two sets of columns, the magnitude of the estimates is larger in absolute value in the DTT sub-sample. If a country has a double taxation agreement with Denmark, then a 10 percentage points decrease in the foreign corporate tax rate below Denmark's rate results in MNCs lowering their unit values by 6.34 percent on average when exporting to that destination. The fall in unit values is slightly larger, 7.17 percent, if focusing on the differentiated goods subsample. This evidence is consistent with DTTs providing incentives for engaging in more profit shifting.

In columns 5 and 6 of Table 6 , we report the estimates from a subsample of countries considered to have judicial systems of poor quality based on Kaufmann, Kraay, and Mastruzzi (2004) measure of 'rule of law'. All else equal, these are the locations where the risk of penalty for profit shifting via transfer pricing is low. As expected, the estimates from columns 5 and 6 are much large in magnitude then their corresponding counterparts from the baseline specification in columns 1 and 2. The results suggests that Danish MNCs lower their unit values by 8.16 percent (8.28 percent for differentiated goods) when exporting to destinations that witness a fall in their corporate tax rate of 10 percentage points below Denmark's tax rate. 
Although our regression analysis delivers a key estimate necessary to evaluate the total income shifted out of Denmark via export price manipulations, we cannot separately identify the transfer price manipulations from the arm's length price manipulations. This is due to the inability to distinguish the export transactions in our data by the type of affiliation between the trading partners.

One way to highlight the extent of transfer price manipulations is to focus on specific firms or markets where we have reasons to expect that a larger share of MNCs' exports happen intrafirm. For that reason, we re-define the treatment variable $D A f f_{i j t}$ to equal one if two conditions are simultaneously satisfied: 1) firm $i$ has majority ownership of at least one affiliate in country $j$ at time $t$, and 2) the average quantity of a good exported to the foreign market increases after establishing a foreign affiliate compared to the pre-ownership period. By adding the second condition as necessary for the treatment group, our intention is to identify from all the instances of foreign firm ownership those cases that not only involve changes in real affiliate activity, but also generate increased intrafirm trade. The drawback of this strategy, however, is that it further reduces the number of treated firms, possibly affecting the model identification and the precision of the estimates.

Columns 7 and 8 of Table 6 report the estimation results based on the redefined DAf $f_{i j t}$ indicator variable. Consistent with our expectation, the coefficients of interest are larger in absolute value relative to the baseline results (columns 1 and 2). Even though the estimated standard errors are large, making the regression coefficients of interest significant only at 10 percent level, we nevertheless find evidence that MNCs lower their export unit values by 10.7 percent (12.85 percent for differentiated goods) in response to a 10 percentage point decrease in the foreign corporate tax relative to Denmark's.

Finally, the last robustness exercise that we consider addresses the possibility of non-linearities in the effect of corporate tax rates on profit shifting via transfer pricing. Back in the methodology section, when formalizing the identification strategy, we have assumed a linear relation for the response in export prices to tax rate differences across locations, as given by equation (30). We now relax this assumption and experiment with the idea that transfer pricing strategies may involve both a level change and a marginal effect that is proportional to the tax wedge between countries.

Several reasons motivate this extension of the baseline empirical regression model. For instance, the rapid expansion of Danish multinationals and the establishment of new foreign affiliates 
may first trigger a one time level change in transfer prices, which then evolves only subsequently and gradually according to the tax rate difference between host and home markets. At the same time, there may be a non-monotonic relation between the tax wedge and the transfer price manipulations across countries, which could affect the slope coefficient but not necessarily the intercept.

To implement empirically this idea, we take the indicator variables identifying whether a country has a higher or lower tax rate relative to the tax rate in Denmark, and interact each one of them with the foreign affiliate indicator to get at the level effect, and with the continuous interaction variable "affiliate $\times$ tax wedge" to obtain the marginal effect. That is, we estimate:

$$
\begin{aligned}
\ln p_{i j k t}=\delta \cdot \operatorname{DAff}_{i j t} & +\left[\beta_{10}+\beta_{11} \cdot\left|\Delta \tau_{j t}\right|\right] \times \operatorname{DAff}_{i j t} \times I^{\text {LowTax }}+\left[\beta_{20}+\beta_{21} \cdot\left|\Delta \tau_{j t}\right|\right] \times \operatorname{DAff}_{i j t} \times I^{\text {HighTax }} \\
& +\theta \cdot X_{i t}+\gamma \cdot X_{j t}+\alpha_{i j k}+\alpha_{t}+\alpha_{t, \text { LowTax }}+\alpha_{t, \text { HighTax }}+\epsilon_{i j k t}
\end{aligned}
$$

Note that if the level effects are zero, i.e., $\beta_{10}=\beta_{20}=0$, then the above regression boils down to the baseline model from equation (35).

Table 7 reports the results from estimating this extended regression using the full data sample. For comparison purposes, column 1 reproduces the baseline estimates from Table 3 while column 2 includes the specification with the additional interaction terms. Interestingly, the estimates suggest that while there is no level change in multinational firms' export unit values to low tax destinations, there is a positive and significant level change in multinational firms' export unit values to high tax countries. So, it is the insignificant but negative slope coefficient on the interaction term between the affiliate indicator and the tax wedge variable that makes the overall transfer price effect in high tax destinations insignificant. Evaluated at the sample average tax wedge, the marginal effects reported at the bottom of Table 7 are significant.

\section{Policy Implications}

This section provides a back-of-the-envelope calculation that quantifies the tax revenue lost by the Danish government due to the profit shifting activities of multinational firms, focusing on transfer price manipulations.

Based on the estimation results from our new affiliate sample that are reported in column 3 of Table 4, a typical Danish multinational firm exporting to a host country with a tax rate that is 6.1 
percentage points lower than Denmark's (i.e., our sample average tax wedge for low tax countries) will sell a given product at a price that is 5.6 percent lower than a pure exporter, on average. This drop in export prices reduces the revenue earned from international transactions by the Danish parent firms, diminishing the income tax base in the home country. To determine the total export revenue underreported to the Danish tax authorities in a given year, we use country specific information on the statutory corporate tax rate difference and calculate the following value: ${ }^{40}$

$$
\text { LostExpRev }=\sum_{j \in \text { LowTax }}\left(\hat{\beta}_{2}\left(\operatorname{tax}_{D k}-\operatorname{tax}_{j}\right) \cdot X_{M N C, j}\right)
$$

where $j$ indexes a destination country with a tax rate lower than Denmark's, $\beta_{2}$ is the coefficient on the interaction term $D A f f_{i j t} \times\left|\Delta \tau_{j t}\right| \times I^{\text {LowTax }}$ from equation (35), and $X_{M N C, j}$ denotes the total volume of exports by Danish multinationals owning at least one affiliate in country $j$.

Using the export data for 2006, the last year of our sample, and the coefficient estimate from our regression specification reported in column 3 of Table 4, we estimate that the Danish multinationals in our sample underreported 141 million USD in export revenues through lower-thanarm's-length transfer prices to affiliates in low tax countries. At a Danish tax rate of 28 percent in 2006, this correspond to 39.5 million USD in forgone corporate tax revenues, the equivalent of 3.24 percent of the 1.2 billion USD in corporate income taxes collected by the Danish treasury from the multinational corporations in the sample. For comparison, a 3.24 percent decrease in corporate taxes collected by the IRS in 2006 would result in a loss of over 10 billion USD in tax receipts by the US government.

\section{Conclusions}

Multinational corporations are beholden to their shareholders to maximize global profits. In pursuit of this goal, firms exploit differences in policies and tax rates across countries to minimize their effective global tax burden. A consequence of reallocating profits across jurisdictions within multinational firms is the erosion of countries' reported income tax bases, despite the actual value of production activities that occur in those countries. Concerns over the extent of tax avoidance by multinational firms have risen so much in recent years that international taxation has now become

\footnotetext{
${ }^{40}$ A similar calculation is done by Bernard, Jensen, and Schott (2006) using estimates based on U.S. data.
} 
a top priority for OECD and G8 member states.

In drafting action plans to fight the tax avoidance practices of multinational firms, tax authorities need to establish the main mechanisms through which profit shifting occurs. This paper contributes towards that goal by providing evidence for profit shifting via transfer price manipulations of exported manufactured goods. Danish firms that own affiliates in low tax countries are found to underprice their exports relative to sales to affiliates in countries with the same tax rate as Denmark.

A contribution of this paper is to highlight a bias in measuring income shifting by comparing transfer prices to controlled affiliates with arm's length prices to uncontrolled third parties. We show that multinationals who trade both with affiliated and unaffiliated parties have an incentive to deviate the arm's length price from profit maximizing levels in order to reduce the gap from transfer prices and thus conceal profit shifting. To correct for this attenuation bias, we propose a triple difference estimation strategy that exploits a novel source of variation coming from the establishment of new plants in foreign markets characterized by various levels of statutory corporate tax rates.

Future research should examine transfer pricing strategies for a multinational firm shipping to multiple destinations. In this study, we concentrate only on bilateral trade between firms and countries in which they have an affiliate. However, we can further correct for international tax planning by studying how multinationals might hide profit shifting in one destination country by manipulating prices in another destination.

\section{References}

Bartelsman, Eric J. and Roel M.W.J. Beetsma. 2003. "Why Pay More? Corporate Tax Avoidance Through Transfer Pricing in OECD Countries." Journal of Public Economics 87:2225-2252.

Bauer, Christian J. and Dominika Langenmayr. 2013. "Sorting Into Outsourcing: Are Profits Taxed at a Gorilla's Arm's Length?" Journal of International Economics , forthcoming.

Bernard, Andrew, Bradford Jensen, and Peter Schott. 2006. "Transfer Pricing by U.S.-based Multinational Firms." NNER, Working Paper 12493. 
Blonigen, Bruce A. and Jeremy Piger. 2012. "Determinants of Foreign Direct Investment." University of Oregon, mimeo.

Cameron, David. 2013. "Prime Minister David Cameron's Speech to the World Economic Forum in Davos." Jan. 24, 2013, http://www.number10.gov.uk/news/prime-minister-david-cameronsspeech-to-the-world-economic-forum-in-davos.

Clausing, Kimberly A. 2003. "Tax-motivated Transfer Pricing and US Intrafirm Trade Prices." Journal of Public Economics 87:2207-2223.

Cristea, Anca D. 2012. "Multinational Production with Costly Communication: The Role of Foreign Skilled Labor." University of Oregon, mimeo.

Desai, Mihir, Fritz Foley, and James R. Hines. 2006. "The Demand for Tax Haven Operations." Journal of Public Economics 90 (3):513 - 531.

Devreux, Michael. 2006. "The Impact of Taxation on the Location of Capital, Firms and Profit: A Survey of Empirical Evidence." Oxford University Centre for Business Taxation, Working Paper No. $07 / 02$.

di Giovanni, Julian. 2005. "What Drives Capital Flows? The Case of Cross-Border M\&A Activity and Financial Deepening." Journal of International Economics 65 (1):127 - 149.

Egger, Peter, Wolfgang Eggert, Christian Kreuschnigg, and Hannes Winner. 2010. "Corporate Taxation, Debt Financing and Foreign Plant Ownership." European Economic Review 54:96107.

Egger, Peter, Wolfgang Eggert, and Hannes Winner. 2010. "Saving Taxes through Foreign Plant Ownership." Journal of International Economics 81:99-108.

Grubert, Harry and John Mutti. 1991. "Taxes, Tariffs and Transfer Pricing in Multinational Corporation Decision Making." Review of Economics and Statistics 17 (2):285-293.

Helpman, Elhanan, Marc Melitz, and Stephen Yeaple. 2004. "Export versus FDI with Heterogeneous Firms." American Economic Review 94:300-316.

Hines, James R. 1996. "Altered States: Taxes and the Location of Foreign Direct Investment in America." The American Economic Review 86 (5):1076-1094.

- 1999. "Lessons from Behavioral Responses to International Taxation." National Tax Journal 52:304-322.

Hines, James R. and Eric M. Rice. 1994. "Fiscal Paradise: Foreign Tax Havens and American Business." Quarterly Journal of Economics 109:149-182.

Huizinga, Harry, Luc Laeven, and Gaetan Nicodeme. 2008. "Capital Structure and International Debt Shifting." Journal of Financial Economics 88:80-118. 
Irarrazabal, Alfonso, Andreas Moxnes, and Luca David Opromolla. 2012. "The Margins of Multinational Production and the Role of Intrafirm Trade." Journal of Political Economy Forthcoming.

Kaufmann, Daniel, Aart Kraay, and Massimo Mastruzzi. 2004. "Governance Matters III: Governance Indicators for 1996 - 2002." The World Bank Economic Review 18 (2):253 - 287.

Keller, Wolfgang and Stephen R. Yeaple. 2012. "The Gravity of Knowledge." American Economic Review Forthcoming.

Kleinert, Jorn and Farid Toubal. 2013. "Production versus Distribution Oriented FDI." Review of World Economics, forthcoming.

KPMG. 2010. "Denmark: Government's Plan of Action for the Taxation of Multinational Companies." www.us.kpmg.com/microsite/taxnewsflash/tp/2010/TNFTP10_44Denmark.html.

Krautheim, Sebastian. 2012. "Heterogeneous Firms, Exporter Networks and the Effect of Distance on International Trade." Journal of International Economics 87 (1):27-35.

Kreuschnigg, Christian and Michael Devreux. 2012. "The Arm's Length Principle and Distorsions to Multinational Firm Organization." Journal of International Economics, forthcoming.

Melitz, Marc. 2003. "The Impact of Trade on Intra-Industry Reallocations and Aggregate Industry Productivity." Econometrica 71 (6):1695-1725.

OECD. 2013. "Addressing Base Erosion and Profit Shifting." OECD Publishing. http://dx.doi.org/10.1787/9789264192744-en.

Raimondos-Moller, Pascalis and Kimberley Scharf. 2002. "Transfer Pricing Rules and Competing Governments." Oxford Economic Papers 54 (2):230-246.

Rauch, James E. 1999. "Networks versus markets in international trade." Journal of International Economics 48 (1):7 - 35.

Swenson, Deborah L. 2001. "Tax Reforms and Evidence of Transfer Pricing." National tax Journal $54(1): 7-25$. 


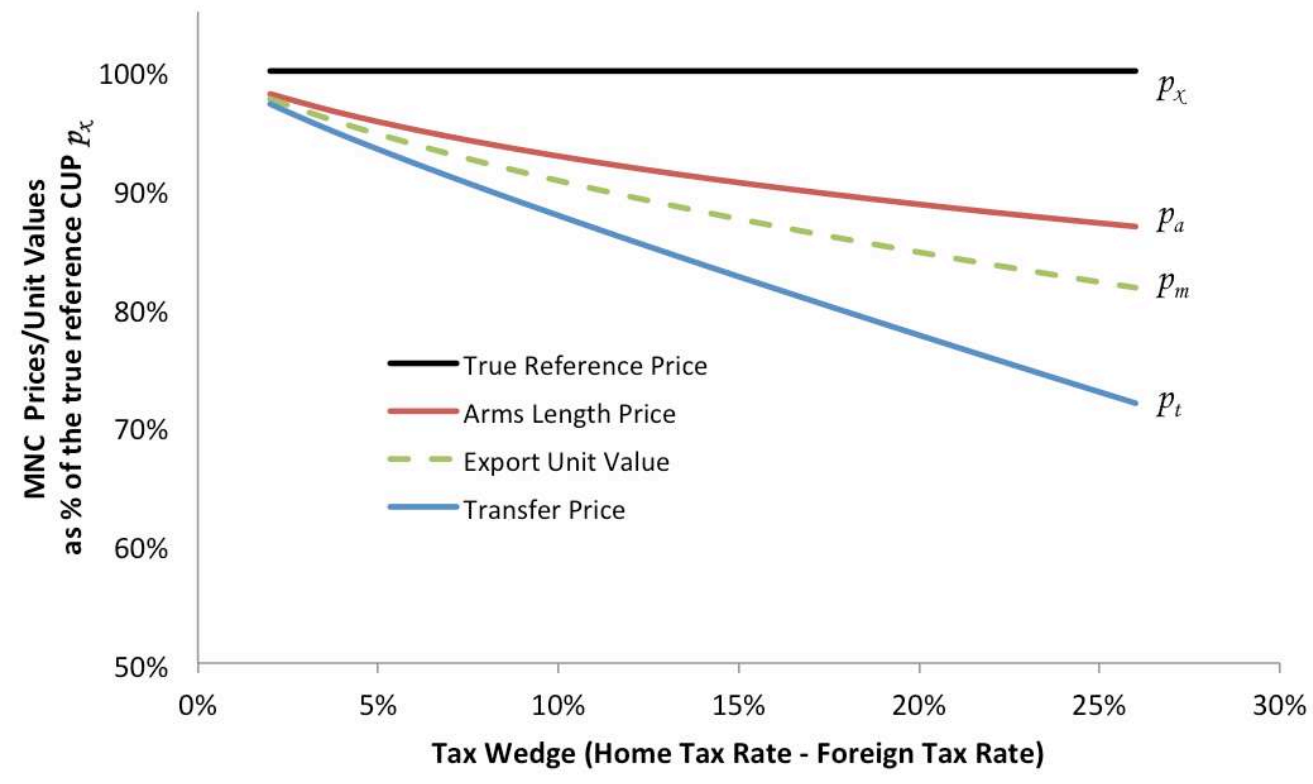

Figure 1: Numerical Solution to the MNC Pricing Decision

Note: The functional forms and parameters used in generating this graph are described in the Appendix.

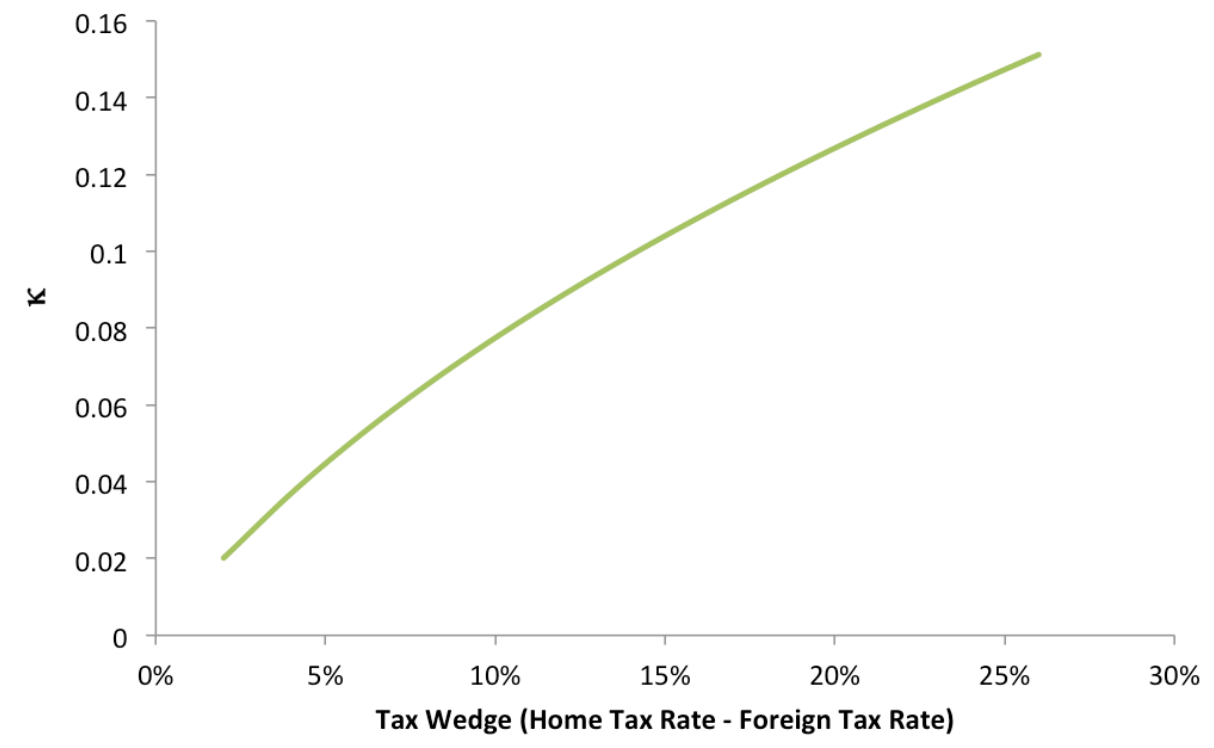

Figure 2: Numerical Solution to the Kappa Function

Note: The functional forms and parameters used in generating this graph are described in the Appendix. 


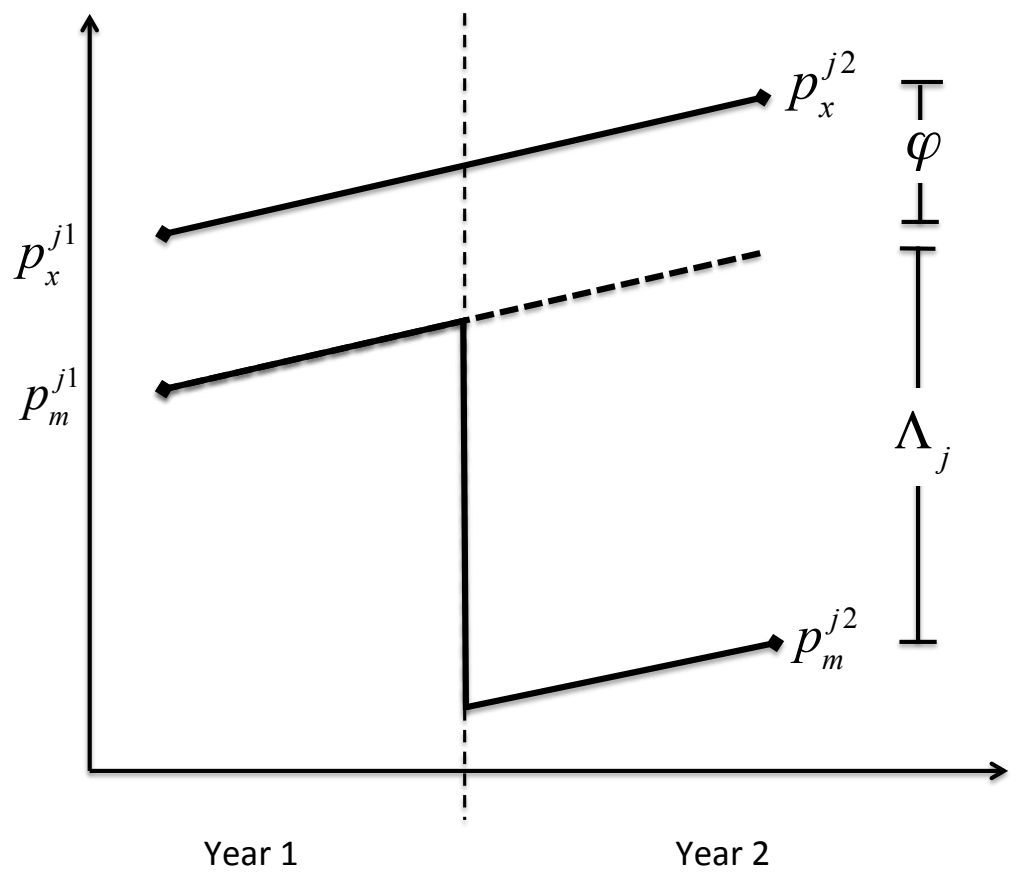

Figure 3: Difference-in-Difference-in-Differences Identification Strategy

Note: The figure above illustrates the movement in export prices for two firms trading in country $j$. The econometrician observes the two export prices $p^{j t}$ for each of two firms, $x$ and $m$. Firm $m$ acquires an affiliate between the two periods. $\varphi$ represents the time-invariant difference in prices across firms (which may or may not be country-specific), as defined in equation (28). $\Lambda_{j}$ represents the change in the export price due to firm $m$ 's acquisition of an affiliate in country $j$, as defined by equation (29). $\Lambda_{j}$ includes both the MNC's price response to tax saving incentives, as well as any other price responses triggered by the firm $m$ 's cross-border expansion of activity. 


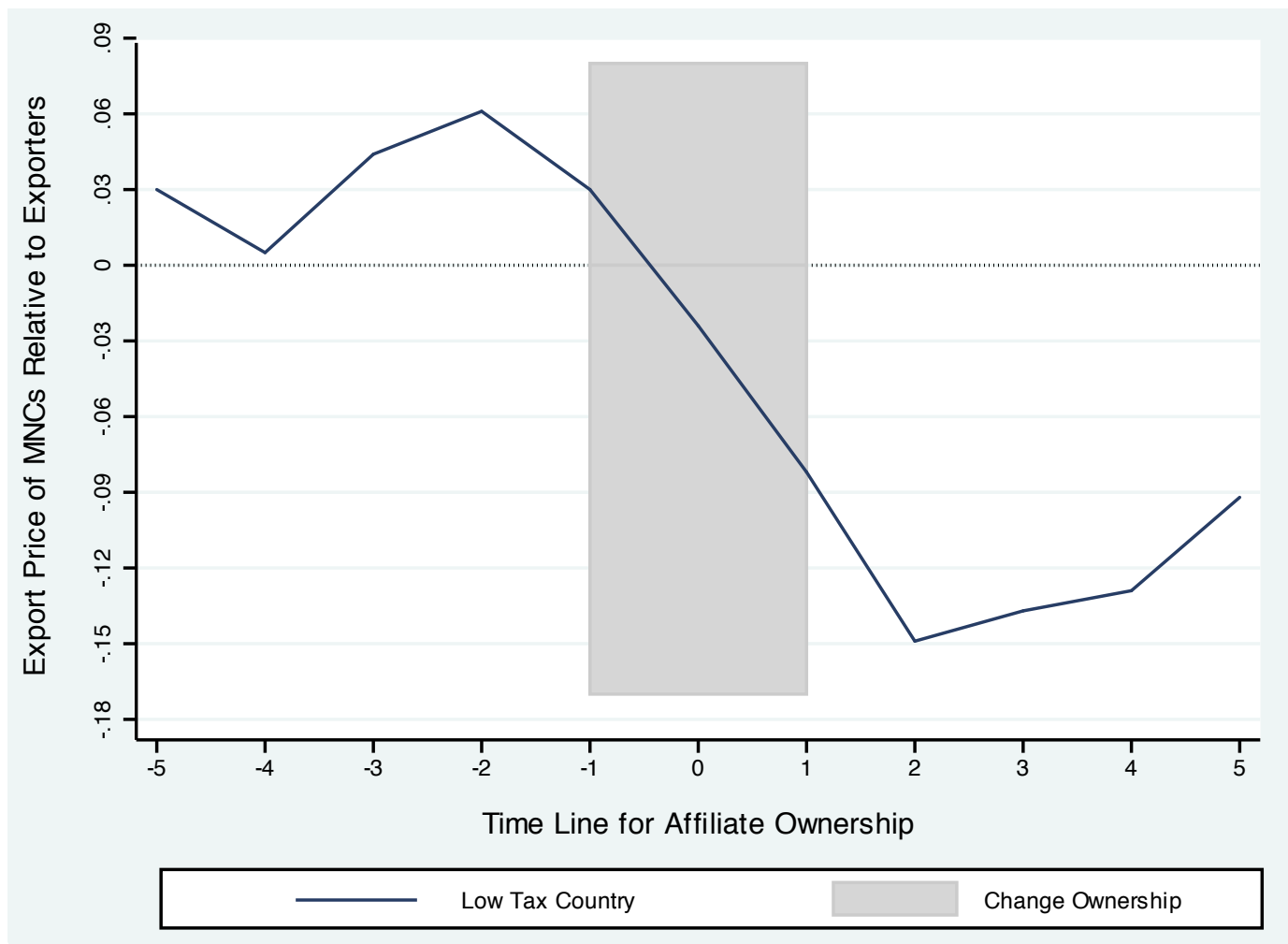

Figure 4: Intra-firm Export Prices relative to Arm's Length by Country Tax Status

Note: The trend lines depicts the average export price charged by a multinational firm relative to an exporting firm for the same product shipped to the same destination market (conditional on time-invariant firm characteristics). The average relative export price is observed for 5 years before and after the multinational establishes its first foreign affiliate in a country, focusing on countries with corporate tax rates below the rate in Denmark. 


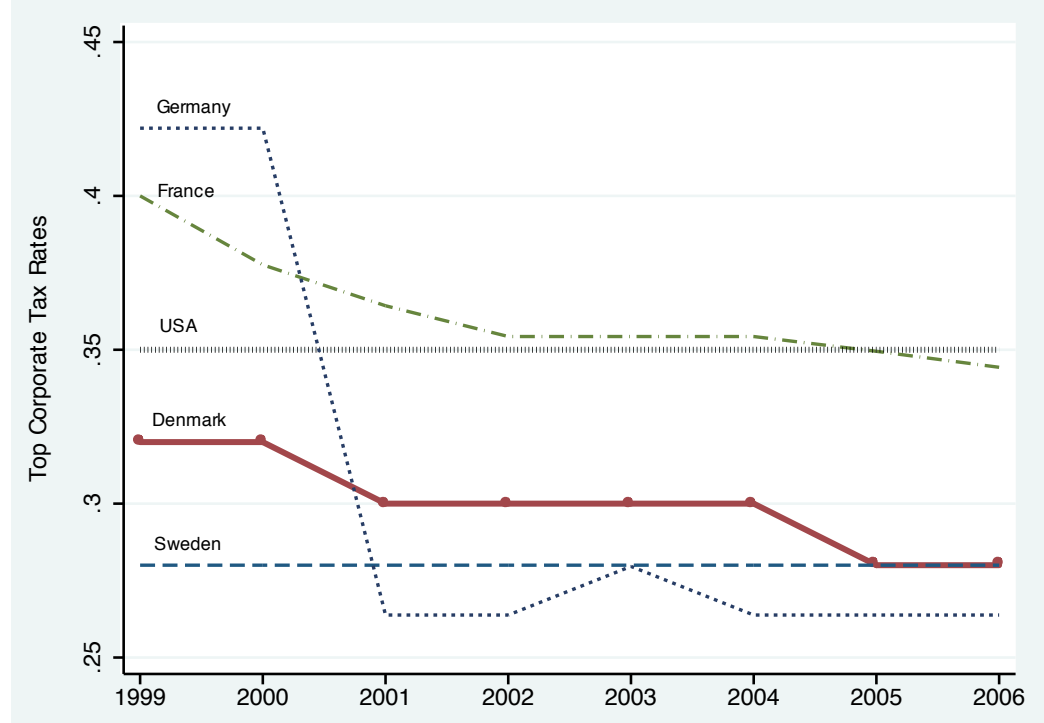

Figure 5: Top Corporate Tax Rates for Denmark and Its Main Trade Partners

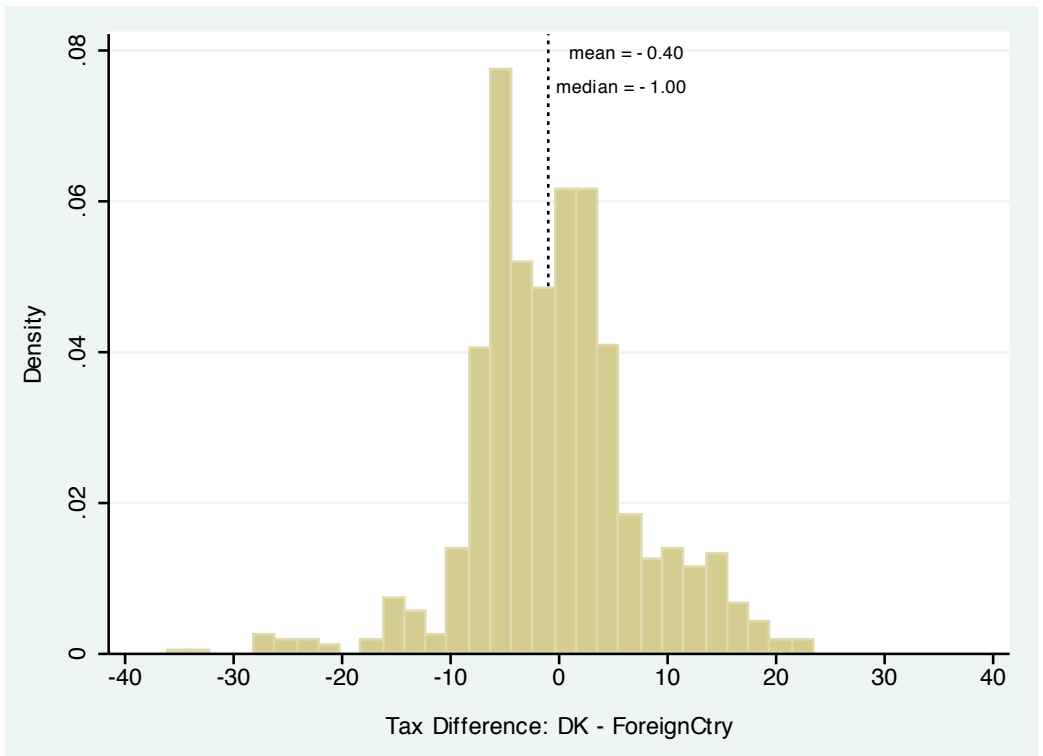

Figure 6: Distribution of Tax Rate Differences among Danish Export Markets 
Table 1: Summary Statistics

\begin{tabular}{|c|c|c|c|c|c|}
\hline & $\begin{array}{c}\text { Mean } \\
(1)\end{array}$ & $\begin{array}{c}\text { St. Dev. } \\
(2)\end{array}$ & $\begin{array}{l}\text { Min } \\
(3)\end{array}$ & $\begin{array}{c}\operatorname{Max} \\
(4)\end{array}$ & $\begin{array}{r}\text { Obs. } \\
(5)\end{array}$ \\
\hline \multicolumn{6}{|l|}{ Firm Characteristics } \\
\hline Log Price & 4.982 & 1.783 & 0.397 & 9.552 & 1203111 \\
\hline Log Quantity & 4.500 & 2.918 & 0.000 & 18.572 & 1203111 \\
\hline Log Employment & 4.556 & 1.654 & -4.605 & 9.440 & 1203111 \\
\hline Log Sales & 11.886 & 1.715 & 0.693 & 17.045 & 1203111 \\
\hline \multicolumn{6}{|l|}{ Firm Level Indicator Variables } \\
\hline Non-MNC Exporters & 0.483 & 0.500 & 0.000 & 1.000 & 1203111 \\
\hline Majority-owned Affiliate (DAff) & 0.114 & 0.317 & 0.000 & 1.000 & 1203111 \\
\hline Acquired Affiliates (during sample) & 0.027 & 0.163 & 0.000 & 1.000 & 1203111 \\
\hline Sold Affiliates (during sample) & 0.011 & 0.106 & 0.000 & 1.000 & 1203111 \\
\hline Foreign owned & 0.178 & 0.382 & 0.000 & 1.000 & 1203111 \\
\hline \multicolumn{6}{|l|}{ Country Characteristics } \\
\hline Log real pcGDP & 11.985 & 0.598 & 9.026 & 13.189 & 1203111 \\
\hline Log Population & 9.776 & 1.577 & 5.625 & 14.089 & 1203111 \\
\hline Log Exchange Rate & 0.786 & 1.765 & -7.897 & 7.882 & 1203111 \\
\hline Statutory Corporate Tax I & 0.283 & 0.069 & 0.085 & 0.450 & 1203111 \\
\hline Low Corporate Tax Rate Dummy & 0.544 & 0.498 & 0.000 & 1.000 & 1203111 \\
\hline High Corporate Tax Rate Dummy & 0.349 & 0.477 & 0.000 & 1.000 & 1203111 \\
\hline$I^{\text {LowTax }} \mathrm{x}\left|\Delta \tau_{j t}\right|$ (Low Tax Wedge) & 0.061 & 0.056 & 0.008 & 0.235 & 653951 \\
\hline$I^{\text {HighTax }} \mathrm{x}\left|\Delta \tau_{j t}\right|$ (High Tax Wedge) & 0.049 & 0.024 & 0.010 & 0.150 & 420397 \\
\hline
\end{tabular}

Table 2: Representation of Danish Multinational Corporations (MNC) in the Trade Data

\begin{tabular}{c|rrr|rrr}
\hline & \multicolumn{3}{|c|}{ Number Firm-Country Pairs } & \multicolumn{3}{c}{ Export Values } \\
\cline { 2 - 7 } Year & Exporters & MNC & \% MNC & All firms & Related Party ${ }^{*}$ & \% Related Party $^{*}$ \\
\hline 1999 & 45650 & 1206 & 2.64 & 203.3 & 40.5 & 19.92 \\
2000 & 46725 & 1309 & 2.80 & 224.3 & 46.4 & 20.69 \\
2001 & 47346 & 1477 & 3.12 & 237.7 & 57.6 & 24.23 \\
2002 & 47976 & 1487 & 3.10 & 233.1 & 66.9 & 28.70 \\
2003 & 46230 & 1586 & 3.43 & 230.3 & 66.0 & 28.66 \\
2004 & 44890 & 1799 & 4.01 & 223.6 & 78.9 & 35.29 \\
2005 & 42497 & 1755 & 4.13 & 229.6 & 77.7 & 33.84 \\
2006 & 43030 & 1907 & 4.43 & 241.1 & 80.2 & 33.26 \\
\hline \hline
\end{tabular}

"Related-party exports are defined as the value of exports by MNCs to those countrieswhere they own an affiliate.

Note: The unit of observation in the dataset used for the constructing the above tabulation is a firm-country-year triplet. This means that every time a firm exports to a new market, or every time a MNC opens an affiliate in a new country, these are counted as though they would be new firms. 
Table 3: Export Price Regression, Full Sample

\begin{tabular}{|c|c|c|c|}
\hline & \multicolumn{3}{|c|}{ Dependent Variable: Log UnitVal ${ }_{i j k t}$} \\
\hline & Basic & Foreign Owned & Pre-MNC Control \\
\hline & $(1)$ & $(2)$ & $(3)$ \\
\hline Affiliate & $\begin{array}{l}0.019 \\
(0.021)\end{array}$ & $\begin{array}{l}0.019 \\
(0.021)\end{array}$ & $\begin{array}{l}0.024 \\
(0.022)\end{array}$ \\
\hline Affiliate $\mathrm{x}\left|\Delta \tau_{j t}\right| \times I^{\text {LowTax }}$ & $\begin{array}{l}-0.570 \\
(0.272)^{* *}\end{array}$ & $\begin{array}{l}-0.571 \\
(0.272)^{* *}\end{array}$ & $\begin{array}{l}-0.533 \\
(0.271)^{* *}\end{array}$ \\
\hline Affiliate $\mathrm{x}\left|\Delta \tau_{j t}\right| \times I^{\text {HighTax }}$ & $\begin{array}{l}0.275 \\
(0.274)\end{array}$ & $\begin{array}{l}0.274 \\
(0.274)\end{array}$ & $\begin{array}{l}0.238 \\
(0.266)\end{array}$ \\
\hline Log Employment & $\begin{array}{c}-0.017 \\
(0.005)^{* * *}\end{array}$ & $\begin{array}{l}-0.017 \\
(0.005)^{* * *}\end{array}$ & $\begin{array}{l}-0.017 \\
(0.005)^{* * *}\end{array}$ \\
\hline Log Sales & $\begin{array}{c}0.017 \\
(0.005)^{* * *}\end{array}$ & $\begin{array}{c}0.017 \\
(0.005)^{* * *}\end{array}$ & $\begin{array}{l}0.017 \\
(0.005)^{* * *}\end{array}$ \\
\hline Corporate Tax Rate & $\begin{array}{l}-0.275 \\
(0.150)^{*}\end{array}$ & $\begin{array}{l}-0.275 \\
(0.150)^{*}\end{array}$ & $\begin{array}{l}-0.270 \\
(0.150)^{*}\end{array}$ \\
\hline Log Population & $\begin{array}{l}-1.034 \\
(0.217)^{* * *}\end{array}$ & $\begin{array}{l}-1.034 \\
(0.217)^{* * *}\end{array}$ & $\begin{array}{l}-1.031 \\
(0.217)^{* * *}\end{array}$ \\
\hline Log real pcGDP & $\begin{array}{l}-0.181 \\
(0.064)^{* * *}\end{array}$ & $\begin{array}{l}-0.181 \\
(0.064)^{* * *}\end{array}$ & $\begin{array}{l}-0.181 \\
(0.064)^{* * *}\end{array}$ \\
\hline Log Exchange Rate & $\begin{array}{c}-0.003 \\
(0.010)\end{array}$ & $\begin{array}{c}-0.003 \\
(0.010)\end{array}$ & $\begin{array}{r}-0.003 \\
(0.010)\end{array}$ \\
\hline Foreign owned & & $\begin{array}{l}0.002 \\
(0.008)\end{array}$ & $\begin{array}{l}0.002 \\
(0.008)\end{array}$ \\
\hline Pre-MNC Indicator x $I^{\text {LowTax }}$ & & & $\begin{array}{l}0.031 \\
(0.023)\end{array}$ \\
\hline Pre-MNC Indicator x $I^{\text {HighTax }}$ & & & $\begin{array}{l}-0.011 \\
(0.029)\end{array}$ \\
\hline Firm x Country x Product FE & yes & yes & yes \\
\hline Tax Regime x Year FE & yes & yes & yes \\
\hline Obs. & $1,203,111$ & $1,203,111$ & $1,203,111$ \\
\hline$R^{2}$ & 0.898 & 0.898 & 0.898 \\
\hline
\end{tabular}

${ }^{* * *} p<0.01,{ }^{* *} p<0.05,{ }^{*} p<0.1$. Standard errors clustered at country-year level in parentheses.

Note: The table examines the effect of statutory corporate tax rates on the export price of Danish MNCs relative to exporter-only firms. The reported estimates correspond to the regression equation (35) in the text. A unit of observation is a firm-destination-product-time quadruple. Affiliate is an indicator variable equal to 1 if the Danish exporter has majority ownership in the destination market. The tax wedge $\left|\Delta \tau_{j t}\right|$ denotes the absolute difference in corporate taxes rates between Denmark and the foreign country, distinguishing between countries with lower $\left(I^{\text {LowTax }}\right)$ or higher tax rates $\left(I^{\text {HighTax }}\right)$. All specifications include a constant, firm-country-product and tax regime specific time effects. 
Table 4: Export Price Regression, Continuous versus New Establishments

\begin{tabular}{|c|c|c|c|}
\hline & \multicolumn{3}{|c|}{ Dependent Variable: Log $U n i t V a l_{i j k t}$} \\
\hline & Continuous & Non-Continuous & New Affiliates \\
\hline & $(1)$ & $(2)$ & $(3)$ \\
\hline Affiliate & & $\begin{array}{l}0.022 \\
(0.022)\end{array}$ & $\begin{array}{c}-0.033 \\
(0.026)\end{array}$ \\
\hline Affiliate $\mathrm{x}\left|\Delta \tau_{j t}\right| \times I^{\text {LowTax }}$ & $\begin{array}{l}-0.636 \\
(0.318)^{* *}\end{array}$ & $\begin{array}{l}-0.824 \\
(0.328)^{* *}\end{array}$ & $\begin{array}{c}-0.913 \\
(0.300)^{* * *}\end{array}$ \\
\hline Affiliate $\mathrm{x}\left|\Delta \tau_{j t}\right| \times I^{\text {HighTax }}$ & $\begin{array}{l}0.027 \\
(0.279)\end{array}$ & $\begin{array}{l}0.466 \\
(0.598)\end{array}$ & $\begin{array}{c}1.261 \\
(0.643)^{*}\end{array}$ \\
\hline Log Employment & $\begin{array}{c}-0.008 \\
(0.006)\end{array}$ & $\begin{array}{c}-0.018 \\
(0.005)^{* * *}\end{array}$ & $\begin{array}{l}-0.021 \\
(0.005)^{* * *}\end{array}$ \\
\hline Log Sales & $\begin{array}{l}0.010 \\
(0.006)\end{array}$ & $\begin{array}{c}0.016 \\
(0.006)^{* * *}\end{array}$ & $\begin{array}{c}0.020 \\
(0.006)^{* * *}\end{array}$ \\
\hline Corporate Tax Rate & $\begin{array}{l}-0.326 \\
(0.192)^{*}\end{array}$ & $\begin{array}{l}-0.249 \\
(0.146)^{*}\end{array}$ & $\begin{array}{c}-0.193 \\
(0.138)\end{array}$ \\
\hline Log Population & $\begin{array}{c}-1.049 \\
(0.294)^{* * *}\end{array}$ & $\begin{array}{l}-1.024 \\
(0.216)^{* * *}\end{array}$ & $\begin{array}{c}-0.889 \\
(0.205)^{* * *}\end{array}$ \\
\hline Log real pcGDP & $\begin{array}{l}-0.156 \\
(0.088)^{*}\end{array}$ & $\begin{array}{c}-0.167 \\
(0.062)^{* * *}\end{array}$ & $\begin{array}{c}-0.167 \\
(0.060)^{* * *}\end{array}$ \\
\hline Log Exchange Rate & $\begin{array}{l}0.007 \\
(0.008)\end{array}$ & $\begin{array}{c}-0.003 \\
(0.009)\end{array}$ & $\begin{array}{r}-0.005 \\
(0.009)\end{array}$ \\
\hline Firm $\mathrm{x}$ Country $\mathrm{x}$ Product FE & yes & yes & yes \\
\hline Tax Regime x Year FE & yes & yes & yes \\
\hline Obs. & 736,228 & 1111520 & $1,083,235$ \\
\hline$R^{2}$ & 0.901 & 0.900 & 0.901 \\
\hline
\end{tabular}

${ }^{* * *} p<0.01,{ }^{* *} p<0.05,{ }^{*} p<0.1$. Standard errors clustered at country-year level in parentheses.

Note: The table examines the effect of statutory corporate tax rates on the export price of Danish MNCs relative to exporter-only firms. The reported coefficients correspond to the regression equation (35) in the text, estimated across three different subsamples. All subsamples include the (common) reference group of exporter-only firms. In addition, the Continuous subsample includes only MNCs that own affiliates in a country throughout the sample period. The Non-Continous subsample includes all MNCs that change their foreign firm ownership in a market. The New Affiliates subsample includes only non-continous MNCs that acquire affiliates in a country during the sample period (rather than sell). All other explanations from the footnote in Table 3 apply. 
Table 5: Export Price Regression, Differentiated Goods Only

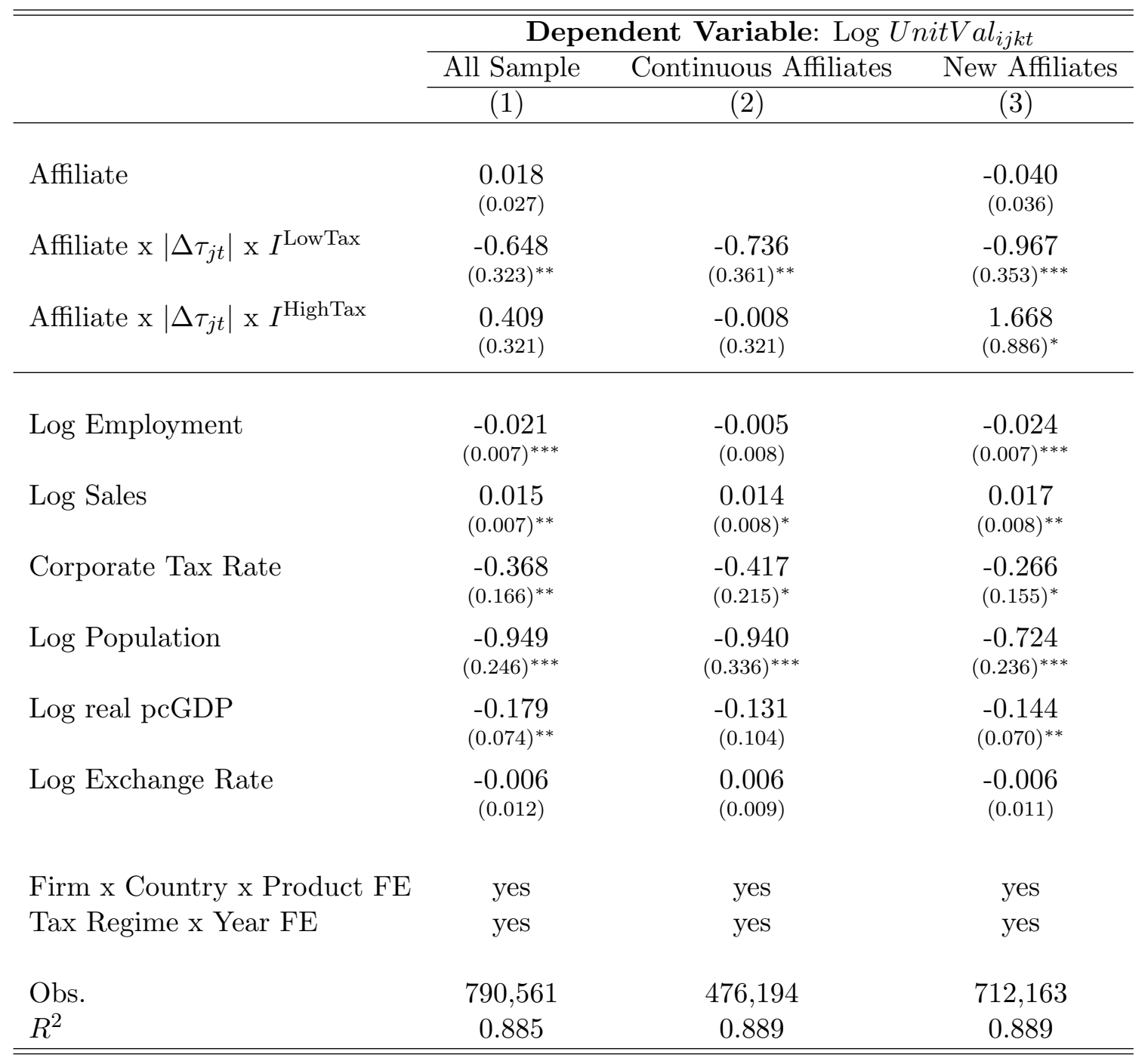

${ }^{* * *} p<0.01,{ }^{* *} p<0.05,{ }^{*} p<0.1$. Standard errors clustered at country-year level in parentheses.

Note: The table examines the effect of statutory corporate tax rates on the export price of Danish MNCs relative to exporter-only firms. The reported coefficients correspond to the regression equation (35) in the text, estimated using exports of differentiated goods only (Rauch (1999) classification) and different data samples. Column 1 includes the trade transactions of differentiated goods carried by all firms, while column 2 and 3 restricts the set of MNCs included in the same way as in columns 1 and 3 of Table 4 respectively. All other explanations from the footnote in Table 3 apply. 
Table 6: Robustness Checks

\begin{tabular}{|c|c|c|c|c|c|c|c|c|}
\hline & \multicolumn{8}{|c|}{ Dependent Variable: Log UnitVal ${ }_{i j k t}$} \\
\hline & \multicolumn{2}{|c|}{ Baseline } & \multicolumn{2}{|c|}{ Double Tax Treaty } & \multicolumn{2}{|c|}{ Poor Judicial Qual. } & \multicolumn{2}{|c|}{ Intra-firm Q Increase } \\
\hline & All Goods & Diff. & All Goods & Diff. & All Goods & Diff. & All Goods & Diff. \\
\hline & $(1)$ & $(2)$ & $(3)$ & $(4)$ & $(5)$ & $(6)$ & $(7)$ & $(8)$ \\
\hline Affiliate & $\begin{array}{l}0.019 \\
(0.021)\end{array}$ & $\begin{array}{l}0.018 \\
(0.027)\end{array}$ & $\begin{array}{l}0.024 \\
(0.027)\end{array}$ & $\begin{array}{l}0.031 \\
(0.035)\end{array}$ & $\begin{array}{l}0.017 \\
(0.047)\end{array}$ & $\begin{array}{l}0.025 \\
(0.058)\end{array}$ & $\begin{array}{c}-0.182 \\
(0.032)^{* * *}\end{array}$ & $\begin{array}{l}-0.186 \\
(0.041)^{* * *}\end{array}$ \\
\hline Affiliate $\mathrm{x}\left|\Delta \tau_{j t}\right| \mathrm{x} I^{\text {LowTax }}$ & $\begin{array}{l}-0.570 \\
(0.272)^{* *}\end{array}$ & $\begin{array}{l}-0.648 \\
(0.323)^{* *}\end{array}$ & $\begin{array}{l}-0.634 \\
(0.291)^{* *}\end{array}$ & $\begin{array}{l}-0.717 \\
(0.358)^{* *}\end{array}$ & $\begin{array}{l}-0.816 \\
(0.356)^{* *}\end{array}$ & $\begin{array}{l}-0.828 \\
(0.462)^{*}\end{array}$ & $\begin{array}{l}-1.072 \\
(0.622)^{*}\end{array}$ & $\begin{array}{l}-1.285 \\
(0.706)^{*}\end{array}$ \\
\hline Affiliate $\mathrm{x}\left|\Delta \tau_{j t}\right| \times I^{\text {HighTax }}$ & $\begin{array}{l}0.275 \\
(0.274)\end{array}$ & $\begin{array}{l}0.409 \\
(0.321)\end{array}$ & $\begin{array}{l}0.304 \\
(0.867)\end{array}$ & $\begin{array}{l}0.395 \\
(0.308)\end{array}$ & $\begin{array}{l}1.251 \\
(0.698)^{*}\end{array}$ & $\begin{array}{l}1.450 \\
(0.941)\end{array}$ & $\begin{array}{l}0.589 \\
(0.867)\end{array}$ & $\begin{array}{l}0.988 \\
(1.037)\end{array}$ \\
\hline Log Employment & $\begin{array}{l}-0.017 \\
(0.005)^{* * *}\end{array}$ & $\begin{array}{l}-0.021 \\
(0.007)^{* * *}\end{array}$ & $\begin{array}{l}-0.020 \\
(0.006)^{* * *}\end{array}$ & $\begin{array}{c}-0.029 \\
(0.007)^{* * *}\end{array}$ & $\begin{array}{l}-0.020 \\
(0.009)^{* *}\end{array}$ & $\begin{array}{l}-0.031 \\
(0.011)^{* * *}\end{array}$ & $\begin{array}{l}-0.017 \\
(0.005)^{* * *}\end{array}$ & $\begin{array}{c}-0.020 \\
(0.007)^{* * *}\end{array}$ \\
\hline Log Sales & $\begin{array}{c}0.017 \\
(0.005)^{* * *}\end{array}$ & $\begin{array}{c}0.015 \\
(0.007)^{* * *}\end{array}$ & $\begin{array}{c}0.015 \\
(0.007)^{* *}\end{array}$ & $\begin{array}{c}0.018 \\
(0.008)^{* *}\end{array}$ & $\begin{array}{c}0.022 \\
(0.010)^{* *}\end{array}$ & $\begin{array}{c}0.026 \\
(0.010)^{* *}\end{array}$ & $\begin{array}{c}0.017 \\
(0.005)^{* * *}\end{array}$ & $\begin{array}{c}0.016 \\
(0.007)^{* *}\end{array}$ \\
\hline Corporate Tax Rate & $\begin{array}{l}-0.275 \\
(0.150)^{*}\end{array}$ & $\begin{array}{l}-0.368 \\
(0.166)^{* *}\end{array}$ & $\begin{array}{l}-0.376 \\
(0.149)^{* *}\end{array}$ & $\begin{array}{l}-0.513 \\
(.169)^{* * *}\end{array}$ & $\begin{array}{l}-0.621 \\
(.170)^{* * *}\end{array}$ & $\begin{array}{l}-0.779 \\
(.181)^{* * *}\end{array}$ & $\begin{array}{r}-0.227 \\
(0.153)\end{array}$ & $\begin{array}{l}-0.316 \\
(0.167)^{*}\end{array}$ \\
\hline Log Population & $\begin{array}{c}-1.034 \\
(0.217)^{* * *}\end{array}$ & $\begin{array}{c}-0.949 \\
(0.246)^{* * *}\end{array}$ & $\begin{array}{c}-1.012 \\
(0.241)^{* * *}\end{array}$ & $\begin{array}{c}-0.971 \\
(0.278)^{* * *}\end{array}$ & $\begin{array}{c}-0.820 \\
(0.276)^{* * *}\end{array}$ & $\begin{array}{l}-0.641 \\
(0.314)^{* *}\end{array}$ & $\begin{array}{c}-1.041 \\
(0.216)^{* * *}\end{array}$ & $\begin{array}{c}-0.952 \\
(0.245)^{* * *}\end{array}$ \\
\hline Log real pcGDP & $\begin{array}{c}-0.181 \\
(0.064)^{* * *}\end{array}$ & $\begin{array}{l}-0.179 \\
(0.074)^{* *}\end{array}$ & $\begin{array}{l}-0.169 \\
(0.068)^{* *}\end{array}$ & $\begin{array}{l}-0.176 \\
(0.080)^{* *}\end{array}$ & $\begin{array}{c}-0.091 \\
(0.088)\end{array}$ & $\begin{array}{r}-0.087 \\
(0.102)\end{array}$ & $\begin{array}{c}-0.172 \\
(0.065)^{* * *}\end{array}$ & $\begin{array}{l}-0.170 \\
(0.074)^{* *}\end{array}$ \\
\hline Log Exchange Rate & $\begin{array}{c}-0.003 \\
(0.010)\end{array}$ & $\begin{array}{c}-0.006 \\
(0.012)\end{array}$ & $\begin{array}{c}-0.004 \\
(0.009)\end{array}$ & $\begin{array}{c}-0.006 \\
(0.011)\end{array}$ & $\begin{array}{c}-0.005 \\
(0.009)\end{array}$ & $\begin{array}{c}-0.008 \\
(0.011)\end{array}$ & $\begin{array}{c}-0.004 \\
(0.010)\end{array}$ & $\begin{array}{c}-0.006 \\
(0.012)\end{array}$ \\
\hline Firm x Country x Product FE & yes & yes & yes & yes & yes & yes & yes & yes \\
\hline Tax Regime x Year FE & yes & yes & yes & yes & yes & yes & yes & yes \\
\hline Obs. & $1,203,111$ & 790,561 & 871,457 & 571,381 & 550,773 & 364,352 & $1,203,111$ & 790,563 \\
\hline$R^{2}$ & 0.898 & 0.885 & 0.896 & 0.883 & 0.900 & 0.888 & 0.898 & 0.885 \\
\hline
\end{tabular}

${ }^{* *} p<0.01,{ }^{* *} p<0.05,{ }^{*} p<0.1$. Standard errors clustered by country-year in parentheses.

Note: The table examines how robust is the effect of statutory corporate tax rates on the export price of Danish MNCs relative to exporter-only firms. The reported coefficients correspond to the regression equation (35) in the text, estimated across various subsamples. All variable descriptions from the footnote in Table 3 apply. For comparison purposes, columns 1 and 2 reproduce prior estimates from Table 3 column 1 and Table 5 column 1 . Columns 3 and 4 are estimated based on a subsample of countries that have a Double Taxation Treaty with Denmark in force. Columns 5 and 6 are obtained based on the bottom half countries ranked in terms of judicial quality (based on Kaufmann, Kraay, and Mastruzzi (2004) measure of 'rule of law'). Finally, columns 7 and 8 are estimated based only on MNCs that establish new affiliates during the sample period and are observed increasing exports to that market post-acquisition. 
Table 7: Export Price Regression, Level Changes and Marginal Effects

\begin{tabular}{|c|c|c|}
\hline & \multirow{2}{*}{\multicolumn{2}{|c|}{$\frac{\text { Dependent Var.: Log UnitVal }}{\text { ijkt }}$}} \\
\hline & & \\
\hline & $(1)$ & $(2)$ \\
\hline Affiliate & $\begin{array}{l}0.019 \\
(0.021)\end{array}$ & $\begin{array}{l}0.002 \\
(0.023)\end{array}$ \\
\hline Affiliate $\mathrm{x} I^{\text {LowTax }}$ & & $\begin{array}{l}0.005 \\
(0.025)\end{array}$ \\
\hline Affiliate $\mathrm{x} I^{\text {LowTax }} \mathrm{x}\left|\Delta \tau_{j t}\right|$ & $\begin{array}{r}-0.570 \\
(0.272)^{* *}\end{array}$ & $\begin{array}{l}-0.490 \\
(0.297)^{*}\end{array}$ \\
\hline Affiliate $\times I^{\text {HighTax }}$ & & $\begin{array}{r}0.061 \\
(0.031)^{* *}\end{array}$ \\
\hline Affiliate $\mathrm{x} I^{\text {HighTax }} \mathrm{x}\left|\Delta \tau_{j t}\right|$ & $\begin{array}{l}0.275 \\
(0.274)\end{array}$ & $\begin{array}{r}-0.341 \\
(0.420)\end{array}$ \\
\hline Log Employment & $\begin{array}{r}-0.017 \\
(0.005)^{* * *}\end{array}$ & $\begin{array}{r}-0.017 \\
(0.005)^{* * *}\end{array}$ \\
\hline Log Sales & $\begin{array}{r}0.017 \\
(0.005)^{* * *}\end{array}$ & $\begin{array}{r}0.017 \\
(0.005)^{* * *}\end{array}$ \\
\hline Corporate Tax Rate & $\begin{array}{l}-0.275 \\
(0.150)^{*}\end{array}$ & $\begin{array}{l}-0.246 \\
(0.146)^{*}\end{array}$ \\
\hline Log Population & $\begin{array}{l}-1.034 \\
(0.217)^{* * *}\end{array}$ & $\begin{array}{r}-1.020 \\
(0.217)^{* * *}\end{array}$ \\
\hline Log real pcGDP & $\begin{array}{r}-0.181 \\
(0.064)^{* * *}\end{array}$ & $\begin{array}{r}-0.177 \\
(0.064)^{* * *}\end{array}$ \\
\hline Log Exchange Rate & $\begin{array}{r}-0.003 \\
(0.010)\end{array}$ & $\begin{array}{r}-0.003 \\
(0.010)\end{array}$ \\
\hline Firm x Country x Product FE & yes & yes \\
\hline Tax Regime x Year FE & yes & yes \\
\hline Obs. & $1,203,111$ & $1,203,111$ \\
\hline$R^{2}$ & 0.898 & 0.898 \\
\hline Marginal Effects: & & \\
\hline Low Tax Country & & $\begin{array}{l}-0.025 \\
(0.015)^{*}\end{array}$ \\
\hline High Tax Country & & $\begin{array}{r}0.045 \\
(0.016)^{* * *}\end{array}$ \\
\hline
\end{tabular}

${ }^{* * *} p<0.01,{ }^{* *} p<0.05,{ }^{*} p<0.1$. Standard errors clustered at country-year level in parentheses. Note: The table investigates non-linearities in the effect of statutory corporate tax rates on the export price of Danish MNCs relative to exporter-only firms. The reported coefficients correspond to the regression equation (36) in the text. All variable descriptions from the footnote in Table 3 apply. All specifications include a constant, firm-country-product and tax regime specific time effects. 


\section{Appendix}

Figures 1 and 2 are generated by solving the model using the equations (5), (11), (13), (12), and the two demand equations:

$$
\begin{aligned}
q_{i} & =p_{i}^{-\sigma} A_{i} \\
q_{a} & =p_{a}^{-\sigma} A_{a}
\end{aligned}
$$

using the following parametrization:

$$
\begin{aligned}
\sigma & =2.3 \\
\tau_{h} & =0.30 \\
c & =1 \\
\lambda & =0.005 \\
A_{i} & =1000 \\
A_{a} & =1000 .
\end{aligned}
$$

